Prepared in cooperation with the U.S. Army Corps of Engineers

\title{
Development of Flood-Inundation Maps for the Mississippi River in Saint Paul, Minnesota
}
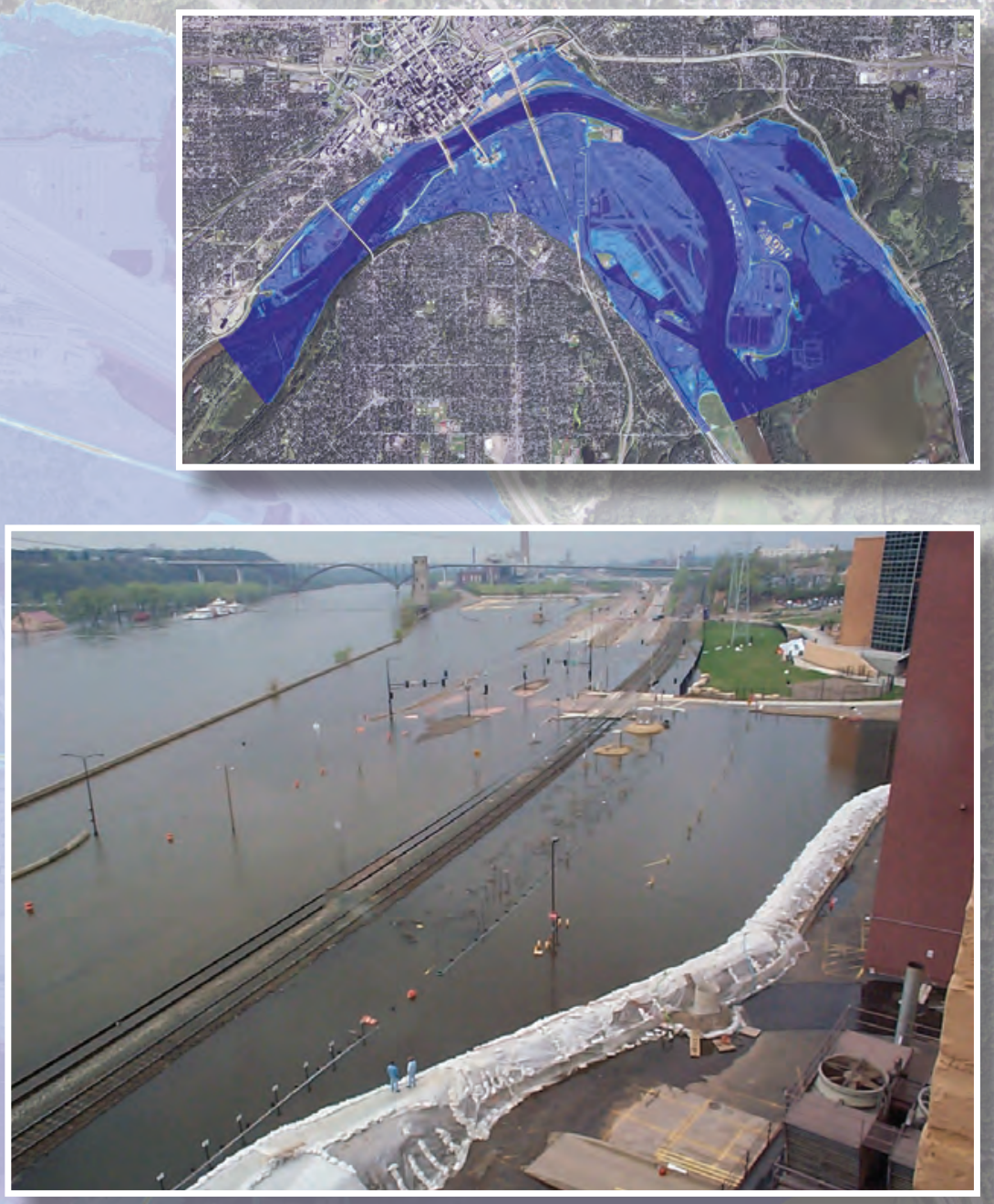

Scientific Investigations Report 2014-5079 
Cover. Top, right: Map showing the estimated depth and extent of flood inundation for the Mississippi River at Saint Paul, Minnesota, at the U.S. Geological Survey streamgage 05331000 , for a corresponding stage of 33.0 feet and an elevation of 716.8 feet above North American Vertical Datum of 1988. Entire map is Map Sheet 25. Map prepared by Christiana Czuba, U.S. Geological Survey, January 2014. Map base from 2010 National Agricultural Imagery program (U.S. Department of Agriculture, 2010).

Bottom, right: Photograph showing inundation along Shepard Road during the April 2001 flood event on the Mississippi River, looking upstream toward the southwest from the north side of the river, with the high bridge at Smith Avenue in the distance, Saint Paul, Minnesota, April 30, 2001. Photo provided by Terry Zien, U.S. Army Corps of Engineers, Saint Paul District. 


\section{Development of Flood-Inundation Maps for the Mississippi River in Saint Paul, Minnesota}

By Christiana R. Czuba, James D. Fallon, Corby R. Lewis, and Diane F. Cooper

Prepared in cooperation with the U.S. Army Corps of Engineers

Scientific Investigations Report 2014-5079 


\title{
U.S. Department of the Interior SALLY JEWELL, Secretary
}

\section{U.S. Geological Survey Suzette M. Kimball, Acting Director}

\author{
U.S. Geological Survey, Reston, Virginia: 2014
}

For more information on the USGS - the Federal source for science about the Earth, its natural and living resources, natural hazards, and the environment, visit http://www.usgs.gov or call 1-888-ASK-USGS.

For an overview of USGS information products, including maps, imagery, and publications, visit http://www.usgs.gov/pubprod

To order this and other USGS information products, visit http://store.usgs.gov

Any use of trade, firm, or product names is for descriptive purposes only and does not imply endorsement by the U.S. Government.

Although this information product, for the most part, is in the public domain, it also may contain copyrighted materials as noted in the text. Permission to reproduce copyrighted items must be secured from the copyright owner.

Suggested citation:

Czuba, C.R., Fallon, J.D., Lewis, C.R., and Cooper, D.F., 2014, Development of flood-inundation maps for the Mississippi River in Saint Paul, Minnesota: U.S. Geological Survey Scientific Investigations Report 2014-5079, 24 p., http://dx.doi.org/10.3133/sir20145079.

ISSN 2328-0328 (online) 


\section{Acknowledgments}

The authors wish to thank the many local, State, and Federal agencies that support the operation and maintenance of the streamgages throughout the country. Special thanks are given to the U.S. Army Corps of Engineers for their cooperation in this study and for the project coordination provided by Terry Zien. Bruce Elder of the city of Saint Paul and Suzanne Jiwani of the Minnesota Department of Natural Resources are thanked for providing valuable data and local information. Jennifer Nelson, the State Hazard Mitigation Officer at Minnesota Homeland Security and Emergency Management, along with other members of the Minnesota Silver Jackets Hazard Mitigation Team, are acknowledged for supporting this study and contributing valuable local knowledge of the study area. Kris Lander of the National Weather Service is thanked for providing thorough reviews of the modeling and mapping products.

Representatives on the U.S. Geological Survey Flood Inundation Mapping team and the Midwest Regional Flood Science Technical Team provided valuable technical expertise. 



\section{Contents}

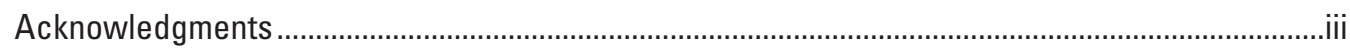

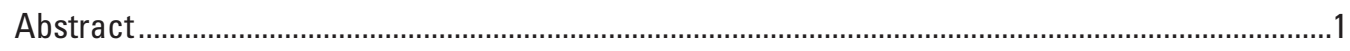

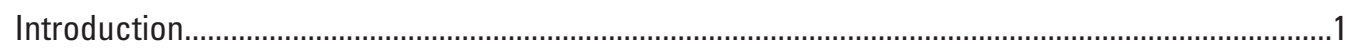

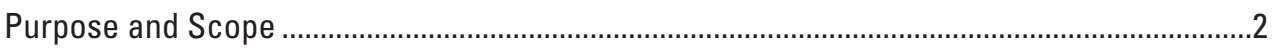

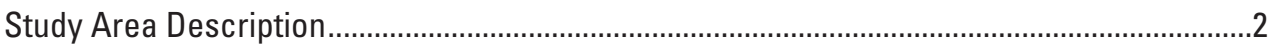

Streamgage and Streamflow History for the Mississippi River at Saint Paul ..........................

Flood Forecasting History for Mississippi River at Saint Paul .................................................8

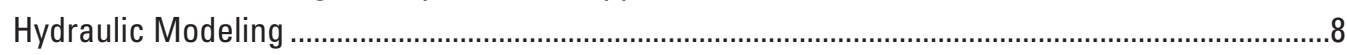

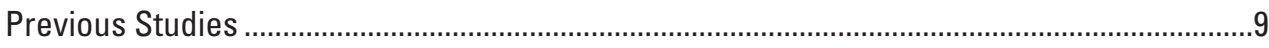

Topographic Data and Model Geometry Inputs.......................................................................

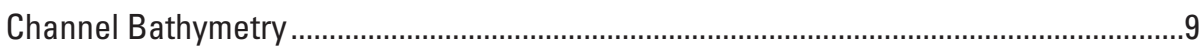

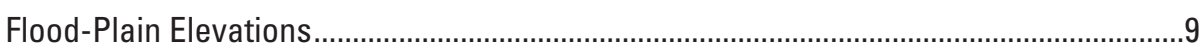

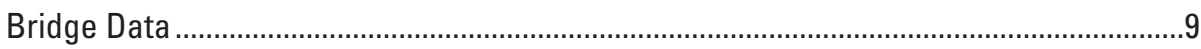

Levees and Flood-Plain Features ................................................................................

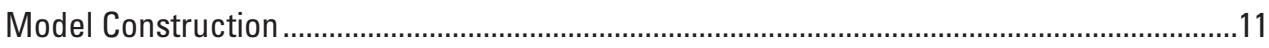

Model Calibration and Performance .....................................................................................11

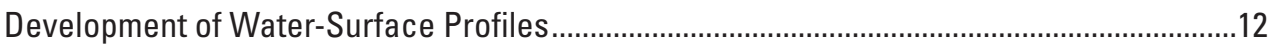

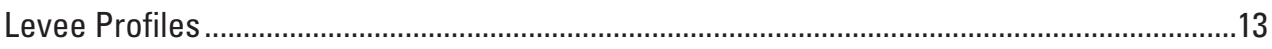

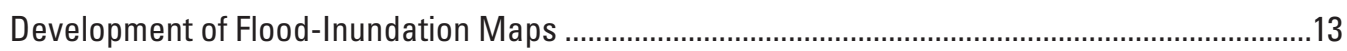

Flood-Inundation Map Library on the Internet..................................................................19

Disclaimer for Flood-Inundation Maps ...........................................................................19

Uncertainties and Limitations Regarding Use of Flood-Inundation Maps ..............................19

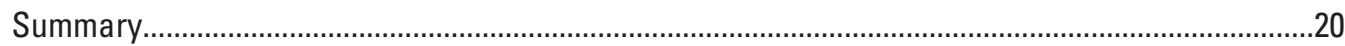

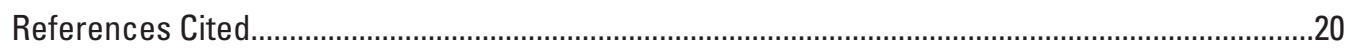

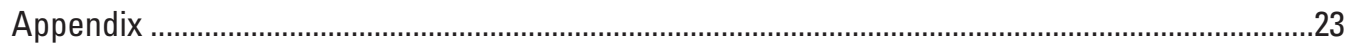

\section{Figures}

1. Map showing location and extent of inundation mapping reach on the Mississippi River and location of the U.S. Geological Survey streamgage 05331000 at Saint Paul, Minnesota

2. Map showing hydraulic model cross-section locations for the Mississippi River

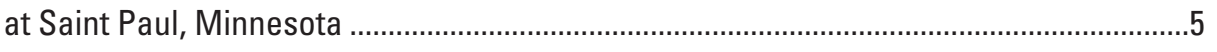

3. Graph showing downstream boundary condition rating curve at Lock and Dam 2........11

4. Graph showing model calibration to rating curve number 38.0 for the Mississippi River at Saint Paul

5. Graph showing comparison of simulated water-surface profiles, the 2011 observed high-water marks, and the flood profile for the existing Flood Insurance Study 1.0-percent exceedance flow .

6. Graphs showing water-surface elevation profiles along the Xcel Energy High Bridge Generating Plant/River Bend Development, Saint Paul, Saint Paul Airport, and Pig's Eye Wastewater Treatment Plant levees. 


\section{Tables}

1. Streamgage information for the Mississippi River near Saint Paul, Minnesota................4

2. Comments on streamgage location or river reach at the Mississippi River at Saint Paul, Minnesota streamgage .....

3. Bridge data included in the 2001 HEC-2 model for the Mississippi River near Saint Paul, Minnesota

4. Additional bridge data not available in the $2001 \mathrm{HEC}-2$ model used for this modeling effort on the Mississippi River near Saint Paul, Minnesota.

5. Levees within the hydraulic model for the Mississippi River near Saint Paul, Minnesota

6. Estimated relation between streamflow and water-surface elevation for the Mississippi River at South Saint Paul.

7. Comparison of calibrated hydraulic model water-surface elevations and rating curve number 38.0 for the Mississippi River at Saint Paul

8. Stage, water-surface elevation, and streamflow simulated in the hydraulic model for development of flood-inundation maps for the Mississippi River at Saint Paul ...

9. Simulated water-surface elevations at selected locations along levees

\section{Conversion Factors and Datums}

\begin{tabular}{|c|c|c|}
\hline Multiply & By & To obtain \\
\hline \multicolumn{3}{|c|}{ Length } \\
\hline inch (in.) & 2.54 & centimeter $(\mathrm{cm})$ \\
\hline foot (ft) & 0.3048 & meter $(\mathrm{m})$ \\
\hline mile (mi) & 1.609 & kilometer $(\mathrm{km})$ \\
\hline \multicolumn{3}{|c|}{ Area } \\
\hline acre & 4,047 & square meter $\left(\mathrm{m}^{2}\right)$ \\
\hline square mile $\left(\mathrm{mi}^{2}\right)$ & 2.590 & square kilometer $\left(\mathrm{km}^{2}\right)$ \\
\hline \multicolumn{3}{|c|}{ Flow rate } \\
\hline cubic foot per second $\left(\mathrm{ft}^{3} / \mathrm{s}\right)$ & 0.02832 & cubic meter per second $\left(\mathrm{m}^{3} / \mathrm{s}\right)$ \\
\hline \multicolumn{3}{|c|}{ Hydraulic gradient } \\
\hline foot per mile ( $\mathrm{ft} / \mathrm{mi})$ & 0.1894 & meter per kilometer $(\mathrm{m} / \mathrm{km})$ \\
\hline
\end{tabular}

Vertical coordinate information is referenced either to (1) stage, the height above an arbitrary datum established at a streamgage, or (2) elevation, the height above the North American Vertical Datum of 1988 (NAVD 88), unless otherwise noted. Data were converted to NAVD 88 from other historical datums according to the following conversions:

National Geodetic Vertical Datum of 1929 (NGVD 29): [feet NAVD 88] = [feet NGVD 29] +0.148 feet

Mean Sea Level of 1912 (MSL 12): [feet NAVD 88] = [feet MSL 12] - 0.33 feet

Horizontal coordinate information is referenced to the North American Datum of 1983 (NAD 83), unless otherwise noted.

Water year is the 12-month period, 0ctober 1 through September 30 , and is designated by the calendar year in which it ends. 


\title{
Abbreviations and Symbols
}

\author{
$\pm \quad$ plus or minus \\ AHPS Advanced Hydrologic Prediction Service \\ DEM digital elevation model \\ FEMA Federal Emergency Management Agency \\ FIS Flood Insurance Study \\ GIS geographic information system \\ HEC-RAS Hydraulic Engineering Center-River Analysis System \\ lidar light detection and ranging \\ NAD 83 North American Datum of 1983 \\ NAVD 88 North American Vertical Datum of 1988 \\ $n \quad$ Manning's roughness coefficient \\ NED National Elevation Dataset \\ NGVD 29 National Geodetic Vertical Datum of 1929 \\ NLD National Levee Database \\ NWS National Weather Service \\ USACE U.S. Army Corps of Engineers \\ USGS U.S. Geological Survey \\ WGS $84 \quad$ World Geodetic System 1984 \\ WWTP wastewater treatment plant
}





\title{
Development of Flood-Inundation Maps for the Mississippi River in Saint Paul, Minnesota
}

\author{
By Christiana R. Czuba, ${ }^{1}$ James D. Fallon, ${ }^{1}$ Corby R. Lewis, ${ }^{2}$ and Diane F. Cooper ${ }^{3}$
}

\section{Abstract}

Digital flood-inundation maps for a 6.3-mile reach of the Mississippi River in Saint Paul, Minnesota, were developed through a multi-agency effort by the U.S. Geological Survey in cooperation with the U.S. Army Corps of Engineers and in collaboration with the National Weather Service. The inundation maps, which can be accessed through the U.S. Geological Survey Flood Inundation Mapping Science Web site at http://water.usgs.gov/osw/flood_inundation/and the National Weather Service Advanced Hydrologic Prediction Service site at http://water.weather.gov/ahps/inundation.php, depict estimates of the areal extent and depth of flooding corresponding to selected water levels (stages) at the U.S. Geological Survey streamgage at the Mississippi River at Saint Paul (05331000). The National Weather Service forecasted peak-stage information at the streamgage may be used in conjunction with the maps developed in this study to show predicted areas of flood inundation.

In this study, flood profiles were computed for the Mississippi River by means of a one-dimensional step-backwater model. The hydraulic model was calibrated using the most recent stage-discharge relation at the Robert Street location (rating curve number 38.0) of the Mississippi River at Saint Paul (streamgage 05331000), as well as an approximate water-surface elevation-discharge relation at the Mississippi River at South Saint Paul (U.S. Army Corps of Engineers streamgage SSPM5). The model also was verified against observed high-water marks from the recent 2011 flood event and the water-surface profile from existing flood insurance studies. The hydraulic model was then used to determine 25 water-surface profiles for flood stages at 1-foot intervals ranging from approximately bankfull stage to greater than the highest recorded stage at streamgage 05331000 . The simulated water-surface profiles were then combined with a geographic information system digital elevation model, derived from high-resolution topography data, to delineate potential areas

\footnotetext{
${ }^{1}$ U.S. Geological Survey.

${ }^{2}$ U.S. Army Corps of Engineers, Saint Paul District.

${ }^{3}$ National Weather Service.
}

flooded and to determine the water depths within the inundated areas for each stage at streamgage 05331000 .

The availability of these maps along with information regarding current stage at the U.S. Geological Survey streamgage and forecasted stages from the National Weather Service provides enhanced flood warning and visualization of the potential effects of a forecasted flood for the city of Saint Paul and its residents. The maps also can aid in emergency management planning and response activities, such as evacuations and road closures, as well as for post-flood recovery efforts.

\section{Introduction}

The city of Saint Paul, Minnesota, was established in 1849 along the banks of the Mississippi River in Ramsey County, Minnesota. Saint Paul is the capital of Minnesota and the second most populous city in the State, with an estimated population of 288,448 in 2011 (U.S. Census Bureau, 2012). Flooding of the Mississippi River in Saint Paul has historically affected both the left bank (commonly known as the east side or Lowertown) and the right bank. Historical flooding has affected neighborhoods in the flood plain since settlement. The greatest recorded flood peaked on April 16, 1965 (U.S. Geological Survey, 2013a).

Following flooding in 1965, the city of Saint Paul has worked with the U.S. Army Corps of Engineers (USACE) and State agencies to mitigate flood hazards. Efforts to date include construction of permanent levees and floodwalls, preservation of open space, and reconstruction and routing of roads (Terry Zien, U.S. Army Corps of Engineers, written commun., 2012). Flood-response plans also identify temporary measures for reduction of flood risk. Although much of the areas that previously flooded now have permanent levees in place, land behind the levees has been developed and the threat of levee failure or a catastrophic flood cannot be discounted.

Before this study, Saint Paul officials relied on several information sources to make decisions on how to best alert the public to imminent flooding and mitigate flood damages. One source is the Federal Emergency Management Agency 
(FEMA) Flood Insurance Study (FIS) for Ramsey, Washington, and Dakota Counties (Federal Emergency Management Agency, 2010a, 2010b, 2011). The FIS provided information on the 1.0- and 0.2-percent annual exceedance probability water-surface profiles and associated flood-plain maps for the Mississippi River. A second source of information is the U.S. Geological Survey (USGS) streamgage on the Mississippi River at Saint Paul (05331000) from which current or historical water levels (stage) can be obtained. A third source is the National Weather Service's (NWS) forecast of peak stage at the USGS streamgage location through the NWS Advanced Hydrologic Prediction Service (AHPS) site (http://water. weather.gov/ahps/). Although USGS current stage and NWS forecast stage information is particularly useful for residents in the immediate vicinity of a streamgage, it is of limited use to residents farther upstream or downstream because the water-surface elevation is not constant along the entire stream channel.

Flood forecast predictions can be better understood visually, in terms of the spatial extent and depth expected to be inundated. By combining streamgage data with hydraulic modeling and digital elevation data, a library of flood-inundation maps was assembled for a series of incremental flood stages and overlain on digital orthophotographs to help show areas of potential flooding. These digital flood-inundation maps were developed for a 6.3-mile (mi) reach of the Mississippi River in Saint Paul through a multi-agency effort by the USGS in cooperation with the USACE and in collaboration with the NWS. Additionally, the flood-inundation maps can be used during nonflood periods for public awareness and emergency management planning. When forecasted floods are imminent, the library of flood-inundation maps allows visualization of areas expected to flood well in advance of the expected peak-flood stage, and can aid in emergency response and flood evacuation procedures.

\section{Purpose and Scope}

The purpose of this report is to describe the development of a series of estimated flood-inundation maps for the Mississippi River in Saint Paul, Minnesota. The flood-inundation maps for the Mississippi River at Saint Paul (USGS streamgage 05331000; also listed as NWS station STPM5) can be accessed through the USGS Flood Inundation Mapping Science Web site (http://water.usgs.gov/osw/flood_inundation/) and the NWS AHPS Inundation Mapping site (http://water. weather.gov/ahps/inundation.php) where viewers can select estimated inundation maps that correspond to the current stage at the USGS streamgage or the NWS forecasted stages.

The scope of the study was limited to the Mississippi River within the city of Saint Paul (fig. 1). Tasks specific to development of the maps were (1) moving and raising a streamgage, (2) computation of water-surface profiles by use of the USACE Hydraulic Engineering Center-River Analysis System (HEC-RAS version 4.1.0) computer program (U.S.
Army Corps of Engineers, 2010), (3) production of estimated flood-inundation maps at various stream stages by use of the USACE HEC-GeoRAS computer program (U.S. Army Corps of Engineers, 2009) and other geographic information system (GIS) tools, and (4) posting the maps to a Web interface that links to USGS real-time streamgage information and NWS forecasted peak stage to facilitate the display of user-selected flood-inundation maps. Maps were produced for water levels (stages) of the Mississippi River at Saint Paul streamgage (05331000) ranging from a stage of 9 feet $(\mathrm{ft})$ to $33 \mathrm{ft}$, which is approximately bankfull stage to greater than the maximum observed stage at the streamgage. In addition to the floodinundation map library published on the Web, the hydraulic model also was used to quantify the water-surface elevations along each of the four levees in the inundation mapping reach to inform city of Saint Paul operations during flood events.

\section{Study Area Description}

Inundation mapping was completed for the Mississippi River within the city limits of Saint Paul, Minnesota. The drainage area is approximately 36,800 square miles $\left(\mathrm{mi}^{2}\right)$ at the Mississippi River at Saint Paul streamgage (05331000). The Mississippi River headwaters originate in central Minnesota, and the river flows generally southward before entering the Saint Paul city limits. The Minnesota River is tributary to the Mississippi River just upstream from Saint Paul. No major tributaries to the Mississippi River join the main stem as it flows through the inundation mapping reach. The inundation mapping reach is approximately 6.3 miles long, has a channel width ranging from about 450 to $1,100 \mathrm{ft}$, and an average channel slope of 0.5 feet per mile (ft/mi) or 0.0001 foot per foot $(\mathrm{ft} / \mathrm{ft})$. The river valley is flanked by high bluffs. The main channel within the inundation mapping reach has 8 bridge crossings, and the adjacent flood plain is primarily urban use.

Average annual precipitation during 1971-2000 was 32.59 inches (in.), and rainfall is typically highest in the summer months, with the highest average in June at $4.98 \mathrm{in}$. (Midwest Regional Climate Center, 2013). Mean monthly streamflow (1892-2012) at the Mississippi River at Saint Paul streamgage (05331000) ranges from 4,850 cubic feet per second $\left(\mathrm{ft}^{3} / \mathrm{s}\right)$ in January to $27,300 \mathrm{ft}^{3} / \mathrm{s}$ in April (U.S. Geological Survey, 2013c).

Data from the Mississippi River at Saint Paul streamgage (05331000; table 1) were used for the analysis of historical streamflow and provided the hydrologic information for the hydraulic model used to develop flood-inundation maps. This streamgage is located roughly near the middle of the inundation mapping reach, approximately $2.5 \mathrm{mi}$ downstream from the upstream mapping study extent. Data from the USACE streamgage at the Mississippi River at South Saint Paul streamgage (SSPM5; fig. 2, table 1) were used for calibration of the downstream portion of the hydraulic model.

Four major levees are within the inundation mapping reach (fig. 1): (1) Saint Paul owns and maintains a levee along 


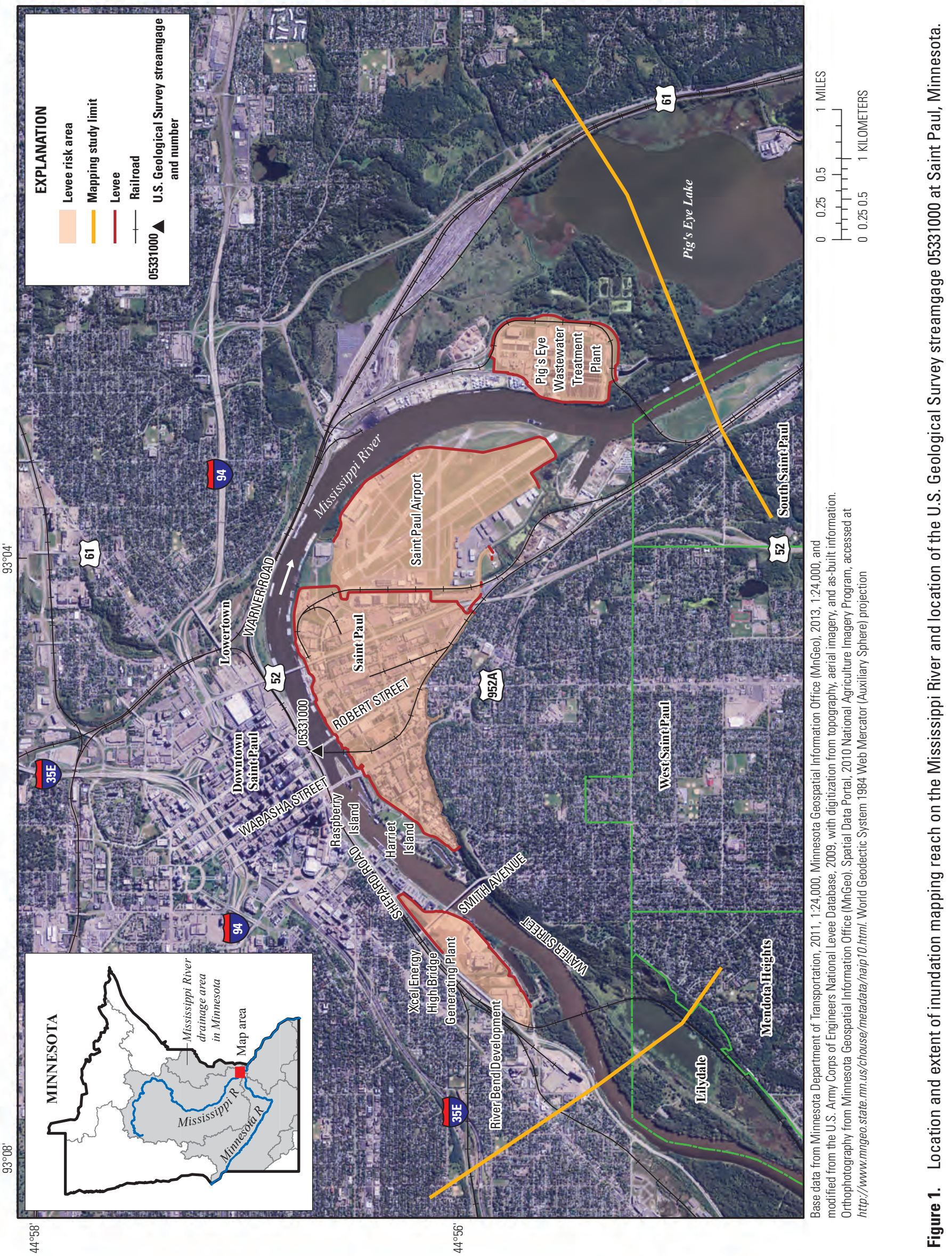


Table 1. Streamgage information for the Mississippi River near Saint Paul, Minnesota.

[Horizontal coordinate data are referenced to the North American Datum of 1983 (NAD 83); mi² $^{2}$ square miles; USGS, U.S. Geological Survey; USACE, U.S. Army Corps of Engineers; Minn., Minnesota; --, not available]

\begin{tabular}{ccccccc}
\hline Station name & Station number & Agency & $\begin{array}{c}\text { Drainage area } \\
\left(\mathbf{m i}^{2}\right)\end{array}$ & $\begin{array}{c}\text { Latitude } \\
\text { (degrees) }\end{array}$ & $\begin{array}{c}\text { Longitude } \\
\text { (degrees) }\end{array}$ & Period of record \\
\hline $\begin{array}{c}\text { Mississippi River at } \\
\text { Saint Paul, Minn. }\end{array}$ & 05331000 & USGS & 36,800 & 44.944447 & -93.088108 & March 1, 1892, to present. ${ }^{1}$ \\
$\begin{array}{c}\text { Mississippi River at } \\
\text { South Saint Paul, } \\
\text { Minn. }\end{array}$ & SSPM5 & USACE & -- & 44.895799 & -93.031049 & January 1, 1988, to present. \\
\hline
\end{tabular}

${ }^{1}$ Although the streamgage existed before March 1, 1892, records before March 1892 have been determined to be unreliable and are not used.

the right bank (south side of the river), (2) a ring levee surrounds the Metropolitan Wastewater Treatment Plant (WWTP) near Pig's Eye Lake, referred to in this report as Pig's Eye WWTP, (3) at the Xcel Energy High Bridge Generating Plant, referred to in this report as Xcel Plant, and River Bend Development and (4) at the Saint Paul Airport (Holman Field). The 3.1-mi long Saint Paul levee was originally constructed in the 1960s, and was then upgraded in June 1995 through designs prepared by or supervised by the USACE to reduce flood risk to 448 acres up to a peak flood streamflow of $210,000 \mathrm{ft}^{3} / \mathrm{s}$, which has an estimated exceedance probability of 0.17 percent or once in 590 years (U.S. Army Corps of Engineers, 1997). The project included raising the flood barrier, upgrading the interior drainage facilities, modifying roadways and access ramps, and acquiring additional real estate for permanent right of way for the flood barrier. The Pig's Eye WWTP is the largest wastewater treatment facility serving the Minneapolis and Saint Paul metropolitan area. The facility is surrounded on all sides by a ring levee and floodwall system. The Xcel Plant has a permanent levee and floodwall system with temporary closure sections. This levee and floodwall system is continued south onto the River Bend Development property, which also includes temporary closures. For higher flood stages, there are supplemental plans for temporary floodwall sections deployable on the northeast part of the Xcel Plant property (Barr Engineering, 2012). A deployable flood barrier system was added to Saint Paul Airport after experiencing substantial flooding in 2001 (Pat Mosites, Metropolitan Airport Commission, written commun., 2013), and the system is operated by the Metropolitan Airport Commission. Some parts of the floodwall are permanent, whereas other parts are built when floods are forecasted, forming a continuous alignment blocking floodwaters from the airport. The airport levee system also is supplemented by temporary measures on the south end of the property, including a retaining wall, a closure structure, and sandbagging/construction of earthen closures.

In other areas of the city, including the Lowertown area, floodwaters are mitigated through temporary emergency methods by way of earthen levees and sandbags, temporary pumps for interior drainage, and blocking of storm sewer outlets. These temporary measures that are not associated with one of the four levees described above are not accounted for in the hydraulic modeling or the inundation mapping in this study.

\section{Streamgage and Streamflow History for the Mississippi River at Saint Paul}

The Mississippi River at Saint Paul is the oldest continuous record streamgage (05331000) in Minnesota. A reliable record of daily or more frequent streamflow data has been collected by the USGS and other Federal agencies since March 1892 (U.S. Geological Survey, 1912). These streamflow records and supporting data, including stage-discharge relations from the streamgage, are used in the hydraulic modeling for flood forecasting and developing the flood-inundation maps for this report.

Occasionally during the operation of a streamgage, changes made to the location, method of operation, or physical setting of the streamgage result in adjustments to the streamflow record. Substantial changes to the streamgage operation at Saint Paul are summarized in table 2, based on records on file at the USGS. Also included in table 2 are the greatest direct measurements made during flood events that define the upper end of the stage-discharge relation. Stage-discharge relations are updated when needed as indicated by direct measurements of stage and streamflow (Rantz and others, 1982). These stage-discharge relations are generally caused by physical changes to the features controlling flow through the channel near the streamgage or by datum changes caused by streamgage relocations. The local datum of the streamgage generally is tied to a national datum [for example, National Geodetic Vertical Datum of 1929 (NGVD 29) or North American Vertical Datum of 1988 (NAVD 88)] so that stage can be converted to water-surface elevation.

In 1866, a manually read, nonrecording gage was established by the U.S. Signal Service at Jackson Street. In 1890, recording of this gage was assumed by the newly formed U.S. Weather Bureau. Records before 1892 were determined to be unreliable and not used by USGS or in this report. From 1892 to 1909 , a nonrecording, daily-read streamgage located on the south side of Broadway Bridge was operated by the U.S. Signal Service although record from this streamgage 


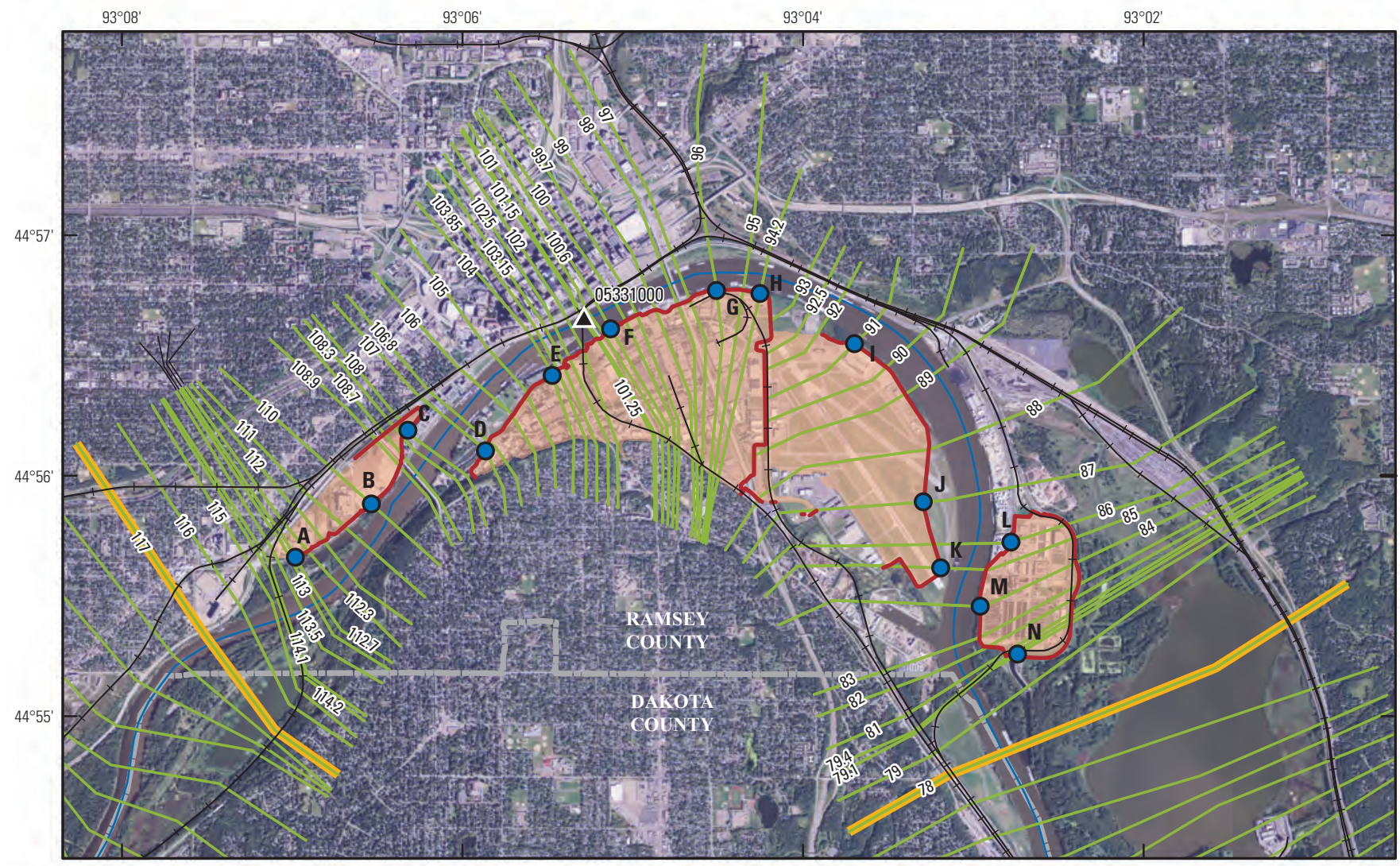

Base data from Minnesota Department of Transportation, 2011, 1:24,000 Minnesota Geospatial Information Office (MnGeo), 2013, 1:24,000, and modified from the U.S. Army Corps of Engineers National Levee Database 2009, with digitization from topography, aerial imagery, and as-built information.

Orthophotography from Minnesota Geospatial Information Office (MnGeo) Spatial Data Portal, 2010 National Agriculture Imagery Program, accessed at http://www.mngeo.state.mn.us/chouse/metadata/naip10.html. World Geodectic System 1984 Web Mercator (Auxiliary Sphere) projection

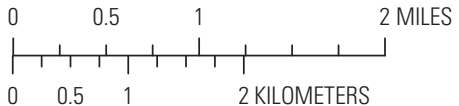

\section{EXPLANATION}

Levee risk area

Mapping study limit

Levee

117 _ Model cross section (and selected numbers)

- River centerline

工 Railroad

AO Cross section of interest with identifier

05331000 \ U.S. Geological Survey streamgage and number SSPM5 $\triangle$ U.S. Army Corps of Engineers streamgage

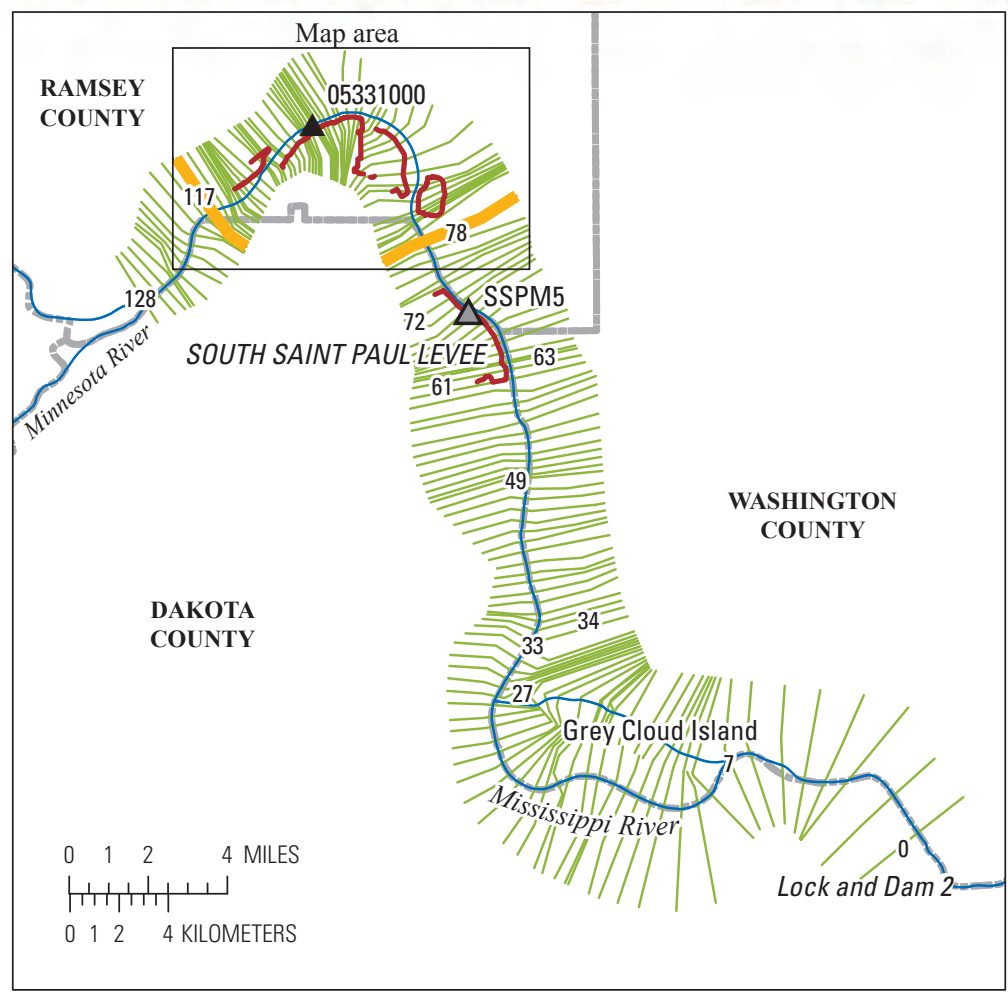

Figure 2. Hydraulic model cross-section locations for the Mississippi River at Saint Paul, Minnesota. 
Table 2. Comments on streamgage location or river reach at the Mississippi River at Saint Paul, Minnesota streamgage (05331000).

[ft, feet; $\mathrm{ft}^{3} / \mathrm{s}$, cubic feet per second; mi, mile; --, not applicable or available; USGS, U.S. Geological Survey; \pm , plus or minus]

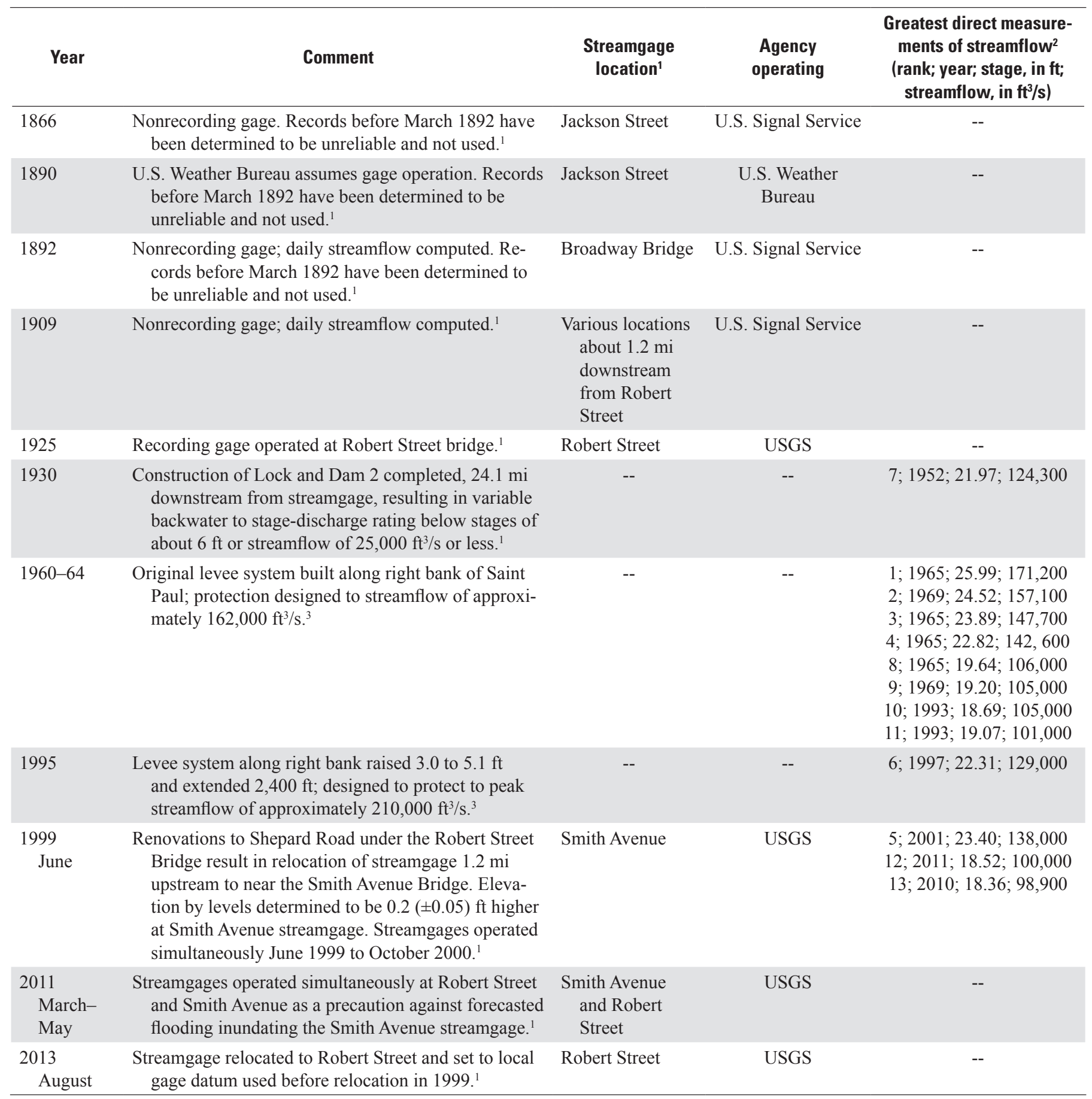

${ }^{1}$ Based on records on file at the U.S. Geological Survey Minnesota Water Science Center.

${ }^{2}$ These are the discrete physical measurements that were collected during each flood event (U.S. Geological Survey, 2013b). Values may be different from reported peak streamflow values (U.S. Geological Survey, 2013a) because (1) measurements were made near, but not at, the peak of the event, or (2) peak streamflow values are determined from stage-discharge relations which are developed as average or weighted curves based on discrete physical measurements and related data.

${ }^{3}$ Terry Zien, U.S. Army Corps of Engineers, written commun., June 2012. 
may not be recoverable. From 1909 to 1925 , nonrecording streamgages were read at several locations within $300 \mathrm{ft}$ of each other approximately $1.2 \mathrm{mi}$ downstream from Robert Street.

In March 1925, a USGS streamgage was established adjacent to the Robert Street Bridge and began the period of continuous recording streamgage data. In 1930, the USACE Lock and Dam 2 (fig. 2) was completed approximately $24.1 \mathrm{mi}$ downstream from Robert Street. Operation of Lock and Dam 2 caused variable backwater affecting the stage-discharge relation of the streamgage below stages of about $6.0 \mathrm{ft}$ or flows of $25,000 \mathrm{ft}^{3} / \mathrm{s}$ or less that continues to present. During 1960-64, the original levee was built along the right bank of Saint Paul, resulting in the general form of the flow path that exists today. In 1995, the levee modifications that raised and extended the system were completed. In June 1999, renovations of Shepard Road under the Robert Street Bridge required the streamgage to be moved 1.2 mi upstream to near Smith Avenue. In 2009, structures were constructed to allow for temporary deployment of a floodwall along the right bank of the Mississippi River at the Saint Paul Airport, about $1 \mathrm{mi}$ downstream from Robert Street. This floodwall can be deployed as needed during major flooding. Although the floodwall was deployed during floods in 2010 and 2011, discrete streamflow measurements have not been made at the streamgage while the floodwall was deployed. From March to May 2011, two streamgages were operated simultaneously at Robert Street and Smith Avenue as a precaution against forecasted flooding that threatened to inundate the Smith Avenue streamgage. In August 2013, the streamgage was re-established at Robert Street.

When the streamgage was relocated to Robert Street in August 2013, the local gage datum was set to the same datum as the former streamgage used at Robert Street so that stage readings are consistent. The new data logging equipment was installed at a higher elevation, ensuring that the streamgage would not be inundated except during the most extreme flood events. In addition, the initial stage-discharge relation used at the new Robert Street streamgage (2013) is the same as the last stage-discharge rating used at Robert Street during 1999 (the rating curve identified as number 38.0 in USGS records for the Mississippi River at Saint Paul streamgage 05331000). This was possible because 10 of 12 historical measurements greater than $100,000 \mathrm{ft}^{3} / \mathrm{s}$ were made before 1999 at the old Robert Street streamgage location (table 2). No adjustments were made to their respective stages, because the remaining three flood measurements made during 2001-11 were within acceptable tolerances to rating curve number 38.0 when adjusted for stage differences between the Robert Street and Smith Avenue streamgages. The stage-discharge relation was defined by rating curve number 38.0 , which provides stage estimates for streamflows as large as $172,000 \mathrm{ft}^{3} / \mathrm{s}$. For streamflows larger than $172,000 \mathrm{ft}^{3} / \mathrm{s}$, the stage-discharge rating has been extrapolated by the USACE based on HEC-RAS modeling results.

The streamgage at the Mississippi River at Saint Paul has recorded many floods since 1892 . There can be multiple floods per year, but a systematic record of the annual peak streamflows allows the calculation of unbiased estimates of annual exceedance probabilities; probabilities in any given year that floods of a given magnitude will be exceeded (computed by water year, defined as October 1 of the previous year to September 30). The greatest flood on record peaked on April 16,1965 , at a streamflow of $171,000 \mathrm{ft}^{3} / \mathrm{s}$ and a peak stage of $26.01 \mathrm{ft}$ (U.S. Geological Survey, 2013a). The 1965 flood has an annual exceedance probability of $0.2-0.5$ percent; that is, between a 1-in-500 and 1-in-200 chance of being exceeded in any given year (Kessler and others, 2013).

The annual peak streamflow record indicates that 9 of the 10 greatest annual peaks were in the latter one-half of the 120-year record $(1951,1952,1965,1969,1993,1997,2001$, 2010, and 2011), and 5 of these peaks within the last 20 years. Most of the annual peak streamflows at the Mississippi River at Saint Paul were from spring snowmelt and early rains during the months of March and April (53 percent), with fewer peaks resulting from rainfall during the late spring-early summer months of May and June (39 percent), or July and August (less than 6 percent).

Annual streamflow peaks do not necessarily correlate with floods of concern. There may be multiple floods at streamflows less than the annual peak in a given year, or conversely, during a dry year the annual peak may not reach a river level that causes flooding. The NWS and city of Saint Paul have identified $14 \mathrm{ft}$ as flood stage for the Mississippi River at Saint Paul streamgage. By assuming that the stagedischarge relation has remained constant during the period of record, and using the discharge corresponding to a stage of $14 \mathrm{ft}$, the streamflow record indicates that flood stage would have been exceeded approximately 265 days during 1892-2012. April was the most frequent month with days exceeding flood stage (170 days), followed by May (35), July, (20), March (19), June (14), October (6), and September (1). There were more than four times more days above flood stage in the latter one-half of the period of record: 217 days during 1953-2012 and 48 days during 1892-1952.

Flood peaks at the Mississippi River at Saint Paul are affected by the timing and magnitude of the peaks from the two major drainage areas upstream: the Minnesota River (46 percent of the drainage area) and Mississippi River (54 percent of the drainage area). The streamgage at the Mississippi River near Anoka (05288500; not shown), measures 96 percent of the drainage area upstream from the confluence with the Minnesota River, and the Minnesota River at Mankato (05325000; not shown) streamgage measures 87 percent of the Minnesota River Basin. The Anoka streamgage began continuous recording in 1931, and the Mankato streamgage began in 1903. The Mississippi River upstream from the confluence with the Minnesota River has a greater drainage area and greater average annual runoff than the Minnesota River Basin (6.0 in. and 3.5 in., respectively), so would be expected to have greater annual peaks and contributions to peaks at Saint Paul than the Minnesota River. Considering the 70 years of record when all three streamgages recorded peaks 
from the same general runoff event (defined as having peaks within 30 days of each other), 77 percent of the time, the Mississippi River at Anoka had a peak streamflow greater than the Minnesota River at Mankato. However, for 8 of the 9 greatest annual peaks at Saint Paul the peak at the Minnesota River at Mankato was greater than the peak at the Mississippi River at Anoka. This indicates that the greatest floods at Saint Paul have been greatly affected by streamflows from the Minnesota River Basin.

\section{Flood Forecasting History for Mississippi River at Saint Paul}

The NWS has developed flood forecast stations at many streamgages, including the Mississippi River at Saint Paul, to provide advanced flood warning. Forecasted flood stages are posted online by the NWS AHPS (http://water.weather.gov/ ahps/). Using observed streamflows at the USGS streamgage (05331000) along with current and forecasted weather conditions, the NWS produces detailed flood forecasts (stages) for the next 7 days for the Mississippi River at Saint Paul (NWS station STPM5). The current NWS flood categories for Saint Paul are: action stage at $10 \mathrm{ft}$, flood stage at $14 \mathrm{ft}$, moderate flood stage at $15 \mathrm{ft}$, and major flood stage at $17 \mathrm{ft}$.

NWS river forecasts for the Mississippi River at Saint Paul date back to at least 1940; however, it is suspected that Saint Paul was 1 of the 26 locations on the Mississippi River with flood warnings issued by the Weather Bureau beginning in 1891 (National Weather Service, 2013), after the streamgage was established in 1866. Following is a brief history of flood forecasting in Saint Paul summarized from various sources (U.S. Department of Commerce and National Oceanic and Atmospheric Administration, 1994; National Weather Service, 2013; and others as noted).

The first documented reference of river forecasts dates to 1940 , establishing a bankfull, or advisory, stage of $8 \mathrm{ft}$ and a flood stage of $14 \mathrm{ft}$ (U.S. Department of Agriculture, 1940). Flood stage was established at the level of flooding at Harriet Island (fig. 1) and the upper levee district. Special advisory forecasts were issued when the river reached $8 \mathrm{ft}$. When the river was expected to reach $14 \mathrm{ft}$ or greater, flood warnings were issued along with the forecasted flood peak information.

During flooding in 1952, warnings of the impending floods were issued 10 days to 2 weeks before the expected flood peak (U.S. Department of Commerce, 1954). Even with this advanced notice of an impending flood, substantial damages were caused by the flooding in Saint Paul, including in the industrial park area, the airport, and the WWTP. For the Mississippi River at Saint Paul, the Weather Bureau office forecasted stages of $15 \mathrm{ft}$, then revised the peak stage to 17-17.5 ft expected on April 12 or 13, 1952 (Wells, 1955). The streamflow of this event observed at the Robert Street streamgage location was substantially higher, peaking at $22.02 \mathrm{ft}$ stage and 125,000 ft $3 / \mathrm{s}$ on April 16, 1952 (U.S. Geological Survey, 2013a).
Before the flood of record peak on April 16, 1965 (stage of $26.01 \mathrm{ft}$ and streamflow of $171,000 \mathrm{ft}^{3} / \mathrm{s}$; U.S. Geological Survey, 2013a), an advisory on the flood potential in the Upper Mississippi River Basin was issued as early as March 19, 1965 (Paulhus and Nelson, 1967). The advisory highlighted that if an additional inch of rain fell just before or during the time of the forecasted peak, then the flood peak would be near the previous record flood from 1952; if greater than one inch of rain fell, then the peak streamflow would be even higher than 1952 streamflows. This 1965 advisory outlook was likely one of the first "spring outlooks" issued for the Mississippi River at Saint Paul, and substantial proactive measures were taken based on this information.

In 1966, with the establishment of the NWS Kansas City River Forecast Center, more advanced river forecasts services were provided for the Mississippi River at Saint Paul. After several substantial floods in 1970s in the upper Midwest and the Red River Valley (not shown), the North Central River Forecast Center was established on July 15, 1979, and began providing forecasts on January 2, 1980. Forecasting for the Mississippi River at Saint Paul was now handled by this new North Central River Forecast Center and 3-day forecasts were provided. In the mid-1990s, forecasted rainfall was incorporated into the river forecast system to provide a context of how any additional rain could affect the river forecasts.

After the 1997 flood on the Mississippi River, forecasts were expanded to a 7-day window. In addition, 3-month probabilistic outlooks were introduced, which substantially enhanced the forecasts by depicting a range of possible conditions, with the 95-percent confidence scenario representing the most likely lowest stage scenario and the 5-percent probability as the most likely highest flood scenario. This was especially useful for snowmelt scenarios in which the statistical analysis was based on current soil conditions and climate from previous years (typically the spring snow season of February, March, and April). The recent (2013) introduction of floodinundation mapping is the newest enhancement to the NWS flood forecasting system, providing a visual context of how the river will affect the landscape as the stage rises.

\section{Hydraulic Modeling}

The water-surface profiles used to produce the 25 floodinundation maps in this study were computed by the USACE using HEC-RAS, version 4.1.0 (U.S. Army Corps of Engineers, 2010). HEC-RAS is a one-dimensional step-backwater hydraulic model for simulation of water-surface profiles with gradually varied, steady-state or unsteady-state flow computation options. Hydraulic analyses for this report were done with the steady-state flow computations.

The HEC-RAS model covers approximately $27.7 \mathrm{mi}$ of the Mississippi River from the confluence with the Minnesota River downstream to Lock and Dam 2 (fig. 2). Of this model extent, a 6.3-mi reach was mapped for this study. Using a 
model that extends well downstream from the area of interest substantially reduces the error expectancy from selection of boundary conditions such that their selection does not substantially affect the water-surface profiles in the inundation mapping reach.

\section{Previous Studies}

Flood Insurance Studies (FISs) for Ramsey, Washington, and Dakota Counties (Federal Emergency Management Agency, 2010a; 2010b; 2011) were completed in 2010 and 2011. Those studies provided information on the water-surface profiles for the 1.0- and 0.2-percent annual exceedance probabilities and associated flood-plain maps for the Mississippi River. Estimates of the peak streamflows along the Mississippi River were $150,000 \mathrm{ft}^{3} / \mathrm{s}$ for the 1.0-percent annual exceedance probability flood and $203,000 \mathrm{ft}^{3} / \mathrm{s}$ for the 0.2 -percent annual exceedance probability flood (Federal Emergency Management Agency, 2010a; 2010b, 2011). For the Mississippi River, all three of these FISs were based on the same HEC-2 (U.S. Army Corps of Engineers, 1991) hydraulic model geometry file dated from 2001.

\section{Topographic Data and Model Geometry Inputs}

An important component of reliable flood-inundation maps is the availability of high-accuracy, detailed topographic data. The hydraulic model was constructed from the best available topographic and bathymetric data that were derived from existing hydraulic models, as-built structure information, one-third arc-second (33-ft; 10-meter) National Elevation Dataset (NED; Gesch and others, 2002), and light detection and ranging (lidar) topography. Cross sections in HEC-RAS generally are approximately perpendicular to the stream at the point the cross section intersects the stream, and each cross section intersects the main channel only once. Various manmade structures (bridges, culverts, roadway embankments, levees, and dams) along the stream have the potential to affect water-surface elevations. Twelve bridges and five levees are represented in the model geometry.

\section{Channel Bathymetry}

All channel bathymetry data are based on field surveys from 1969 to 1972, described by Minnesota Department of Natural Resources (1972) and incorporated into all FIS model studies to date. The in-channel elevations from the existing HEC-2 model were incorporated into the HEC-RAS model for all cross sections.

\section{Flood-Plain Elevations}

Overbank elevations in the existing HEC-2 model were based on field surveys and contour data from the 1970s. Lidar topography data became available for Ramsey and Dakota Counties (with some overlap into Washington County) during the course of this study, which allowed the model cross sections 128 to 34 to be updated with lidar elevations in the flood plain. This extent includes the entire inundation mapping reach (cross sections 117 to 78; fig. 2). The remaining downstream cross sections, where lidar was not yet available (cross sections 33 to 0 and along the side channel around Grey Cloud Island), were constructed from one-third arc-second (33-ft; 10-meter) NED elevations in the overbank area.

The lidar topography data were collected in spring and fall 2011. The processed lidar elevation data were available from the Minnesota Department of Natural Resources as a 1-meter (3-ft) digital elevation model (DEM), with a vertical accuracy of 5 centimeters, or 1.97 in. (Fugro Horizons, Inc., and Minnesota Department of Natural Resources, 2013). The lidar data were downloaded from the Minnesota Geospatial Information Office (http://www.mngeo.state.mn.us/chouse/ elevation/lidar.html), as bare-earth DEMs that are free of vegetation, buildings, and other man-made structures (Minnesota Geospatial Information Office, 2012). The 2011 lidar data were used to provide digital elevation data for the overbanks.

\section{Bridge Data}

The existing HEC-2 models included structural data for some of the current structures in the model reach. Additional bridges, as well as modifications to bridges, were entered into the model using new structural information as appropriate.

The primary source of bridge data is the HEC- 2 model dated from 2001 that is associated with the 2010 Ramsey County FIS (Federal Emergency Management Agency, 2010a), 2010 Washington County FIS (Federal Emergency Management Agency, 2010b), and 2011 Dakota County FIS (Federal Emergency Management Agency, 2011). This model included the geometry representative of current conditions for most bridges including (but not limited to) recent changes to three of the bridges in the model reach (table 3 ). Additional

Table 3. Bridge data included in the $2001 \mathrm{HEC}-2$ model for the Mississippi River near Saint Paul, Minnesota.

\begin{tabular}{clc}
\hline $\begin{array}{c}\text { Model } \\
\text { cross } \\
\text { section }\end{array}$ & Location & $\begin{array}{c}\text { Approximate } \\
\text { year } \\
\text { completed }\end{array}$ \\
\hline 108.8 & Smith Avenue Bridge replacement & 1987 \\
\hline 103.775 & Raspberry Island Bridge construction & 2000 \\
103.775 & Wabasha Bridge replacement & 1998 \\
\hline
\end{tabular}


bridge modifications since the 2001 modeling efforts also were incorporated into this current modeling effort (table 4).

\section{Levees and Flood-Plain Features}

Five levees were represented in the HEC-RAS model (table 5); only four of these levees are within the inundation mapping reach. Levee alignments were assigned in the model based on the USACE National Levee Database (NLD; http://nld.usace.army.mil/), as-built information, and lidar topography (table 5). Elevations of the earthen embankments were obtained from the USACE NLD or lidar elevations, as appropriate. Elevations of floodwalls or other structural elements not apparent in lidar topography were obtained from the USACE NLD or as-built information.

Additional features in the flood plain were captured in the topography data. For example, new housing developments near the river that were not represented in the 2001 HEC-2 model are represented in the 2011 lidar topography.

Table 4. Additional bridge data not available in the $2001 \mathrm{HEC}-2$ model used for this modeling effort on the Mississippi River near Saint Paul, Minnesota.

[MNDOT; Minnesota Department of Transportation]

\begin{tabular}{|c|c|c|c|}
\hline $\begin{array}{c}\text { Model } \\
\text { cross section }\end{array}$ & Bridge & Data source & Status in HEC-RAS model \\
\hline 114.15 & Omaha Road Railroad Bridge & $\begin{array}{l}\text { Original (1915) as-built } \\
\text { drawings provided by } \\
\text { Union Pacific (written } \\
\text { commun., August 2012) }\end{array}$ & Included. \\
\hline 97.45 & $\begin{array}{l}\text { Highway } 52 \text { / Lafayette Bridge } \\
\text { replacement }\end{array}$ & $\begin{array}{l}\text { MNDOT modeling dated } \\
\text { March } 2012\end{array}$ & $\begin{array}{l}\text { Although the Lafayette Bridge replacement is } \\
\text { currently (2014) under construction, the model } \\
\text { included the final design of the two completed } \\
\text { bridge spans. }\end{array}$ \\
\hline 62.5 & Wakota (I-494) Bridge replacement & $\begin{array}{l}\text { MNDOT modeling dated } \\
\text { February } 2002\end{array}$ & Included. \\
\hline 49.15 & Rock Island Bridge removal & $\begin{array}{l}\text { Barr Engineering modeling } \\
\text { dated October } 2011\end{array}$ & $\begin{array}{l}\text { Included (bridge span removal and pier modifica- } \\
\text { tion included in model). }\end{array}$ \\
\hline
\end{tabular}

Table 5. Levees within the hydraulic model for the Mississippi River near Saint Paul, Minnesota.

[USACE, U.S. Army Corps of Engineers; NLD, National Levee Database; LOMR, Letter of Map Revision; MAC; Metropolitan Airport Commission; FEMA; Federal Emergency Management Agency]

\begin{tabular}{|c|c|c|c|}
\hline $\begin{array}{l}\text { Upstream } \\
\text { model cross } \\
\text { section }\end{array}$ & $\begin{array}{l}\text { Downstream } \\
\text { model cross } \\
\text { section }\end{array}$ & Feature & Data source \\
\hline 112.7 & 108 & $\begin{array}{l}\text { Xcel Plant/River Bend } \\
\text { Development levee }\end{array}$ & $\begin{array}{l}\text { Design drawings provided by Xcel Energy and city of Saint Paul (Jeff } \\
\text { Berrington, Xcel Energy, written commun., March 2012). }\end{array}$ \\
\hline 107 & ${ }^{1} 94.2$ & USACE Saint Paul levee & Profile survey in the 2009 USACE NLD. \\
\hline 86 & 79.1 & $\begin{array}{l}\text { Pig's Eye wastewater treat- } \\
\text { ment plant levee }{ }^{2}\end{array}$ & $\begin{array}{l}\text { Levee design profile information in FEMA accreditation documentation } \\
\text { (Roger Denick, STARR-FEMA Region V Support Center, written } \\
\text { commun., May 2012). }\end{array}$ \\
\hline 72 & 61 & $\begin{array}{l}\text { USACE South Saint Paul } \\
\text { levee }\end{array}$ & Profile survey in the 2009 USACE NLD. \\
\hline
\end{tabular}

${ }^{1}$ Levee curves south and is not adjacent to the river at this point (see fig. 2). However, the levee extends downstream adjacent to cross sections 93 to 89 and is represented in the hydraulic model as a lateral structure.

${ }^{2}$ This ring-shaped levee intersects each cross section twice within the left overbank area, and is represented in the model by ineffective flow area rather than a levee feature. 


\section{Model Construction}

The HEC-RAS model was constructed from the previously described datasets using river stationing and crosssection numbers consistent with the 2001 FIS HEC-2 model. The conversion of the 2001 FIS HEC-2 model to HEC-RAS was supplemented by oblique aerial photos and street views (available in Google Earth and online at https://www.google. com/maps) when necessary. The cross sections were extended in several areas to appropriately simulate the conveyance for floods much larger than the annual exceedance probability of 0.2 percent (1-in-500 chance of being exceeded in any given year). The layout of the cross sections was adjusted in many cases to adequately represent the flow through the system for the full range of flood magnitudes. Final cross-section placement and layout can be seen in figure 2. Engineering judgment based on similar models was used to specify values of the roughness coefficients, expansion and contraction coefficients, bridge modeling approach and associated parameters, and weir flow coefficients throughout the model.

Of note for flood-plain structures, the alignment and elevation of the downstream part of the USACE Saint Paul levee that runs north-south (fig. 2) were represented in the HEC-RAS model by a lateral structure on the right edge of cross sections 93 to 89. In addition, because the Pig's Eye WWTP ring-shaped levee crosses each cross section twice (fig. 2), and at higher streamflows, water can flow around the east side of this property, the levee feature was represented in the model by a section of ineffective flow between the levee points, rather than as a levee feature. Other ineffective flow limits also were included in areas that do not actively convey water in a downstream direction, such as the "shadow" areas downstream from high embankments that run perpendicular to the flood plain.

The downstream boundary condition at Lock and Dam 2 (model cross section 0 ) was specified as a rating curve based on the operation manual (U.S. Army Corps of Engineers, 2003) and extrapolated for higher streamflows with a normal depth assumption (fig. 3). The extension of the rating curve using normal depth assumes uniform flow (Chow, 1959) at the most downstream cross section in the HEC-RAS model but is not intended to accurately represent the water surface at that location. Natural rivers typically have cross sections that vary along their length and therefore rarely exhibit uniform flow. The extension of the rating curve at Lock and Dam 2 was done simply to provide a reasonable estimate of the water surface to use as the HEC-RAS downstream boundary condition. The location of the downstream extent of the model was chosen well downstream of the study area such that any errors introduced at the boundary would not affect results within the study area.

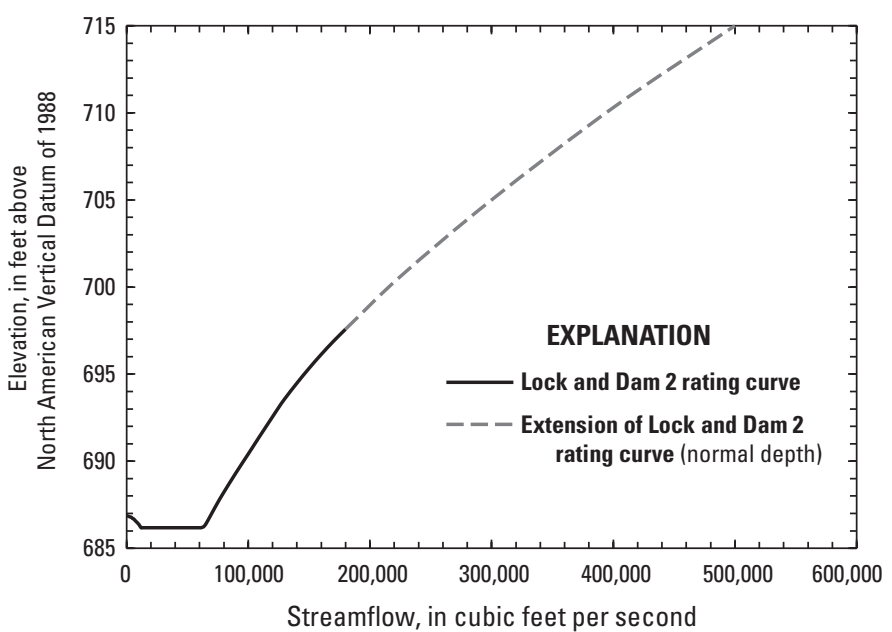

Figure 3. Downstream boundary condition rating curve at Lock and Dam 2.

\section{Model Calibration and Performance}

After the HEC-RAS hydraulic geometry was constructed from the best available current conditions, the hydraulic model was calibrated to the most recent stage-discharge relation at the Robert Street location (rating curve number 38.0) of the Mississippi River at Saint Paul streamgage (05331000). Data from the USACE streamgage at South Saint Paul (SSPM5) was used as a secondary guide for calibration, although no official stage-discharge relation has been developed at this location. An approximate water-surface elevation-discharge relation for SSPM5 (table 6) was estimated using the annual peak water-surface elevation data for the years 1989-2012,

Table 6. Estimated relation between streamflow and watersurface elevation for the Mississippi River at South Saint Paul (U.S. Army Corps of Engineers streamgage SSPM5).

$\left[\mathrm{ft}^{3} / \mathrm{s}\right.$, cubic feet per second; elevations are measured above North American Vertical Datum of 1988 (NAVD 88)]

\begin{tabular}{cc}
\hline $\begin{array}{c}\text { Streamflow, } \\
\text { in } \mathbf{f t}^{3} / \mathbf{s}\end{array}$ & $\begin{array}{c}\text { Water-surface elevation, } \\
\text { in feet }\end{array}$ \\
\hline 60,000 & 693.19 \\
70,000 & 694.56 \\
80,000 & 695.87 \\
90,000 & 697.12 \\
100,000 & 698.31 \\
110,000 & 699.44 \\
120,000 & 700.51 \\
130,000 & 701.52 \\
140,000 & 702.47 \\
\hline
\end{tabular}


assuming that the peak streamflow at South Saint Paul (SSPM5) was equal to the peak streamflow upstream at the streamgage in Saint Paul (05331000) for each flood event. The objective of model calibration was to minimize the difference between observed and simulated water-surface elevations for specific streamflows, giving the highest priority to the published stage-discharge relation at the Robert Street location of the Mississippi River at Saint Paul streamgage (05331000). High-water marks surveyed by the city of Saint Paul after the March 29, 2011, flooding (estimated peak streamflow of $103,000 \mathrm{ft}^{3} / \mathrm{s}$; U.S. Geological Survey, 2013a) and FEMA FIS flood elevations for the 1.0-percent exceedance flow also were used to verify the water-surface profiles simulated using HEC-RAS.

The primary parameters that were altered to match the calibration points were the Manning's roughness coefficient (" $n$ " values) and the use of ineffective flow areas. The final Manning's $n$ values used for the model ranged from 0.025 to 0.032 in the main channel and from 0.085 to 0.115 in the overbank. In-channel Manning's $n$ values were reduced by 15 percent for streamflows less than $75,000 \mathrm{ft}^{3} / \mathrm{s}$ to match the rating curve for all streamflow conditions. Differences between observed and simulated water levels for measured or rated streamflows at USGS streamgage 05331000 were less than or equal to plus or minus $( \pm) 0.5 \mathrm{ft}$ for the entire range of the rating curve (fig. 4; table 7). The model simulated watersurface elevations were within $\pm 0.1 \mathrm{ft}$ of the approximate water-surface elevation-discharge relation at the South Saint Paul streamgage (USACE SSPM5; relation shown in table 6).

Model simulated water-surface elevations were compared to high-water marks surveyed by the city of Saint Paul after the March 2011 flooding (fig. 5). The calibrated model simulated water levels for the 2011 flood peak are within $0.8 \mathrm{ft}$ of the observed high-water marks. A comparison to the FIS 1.0-percent exceedance streamflow $\left(150,000 \mathrm{ft}^{3} / \mathrm{s}\right)$ also indicates that this modeling effort produces similar results

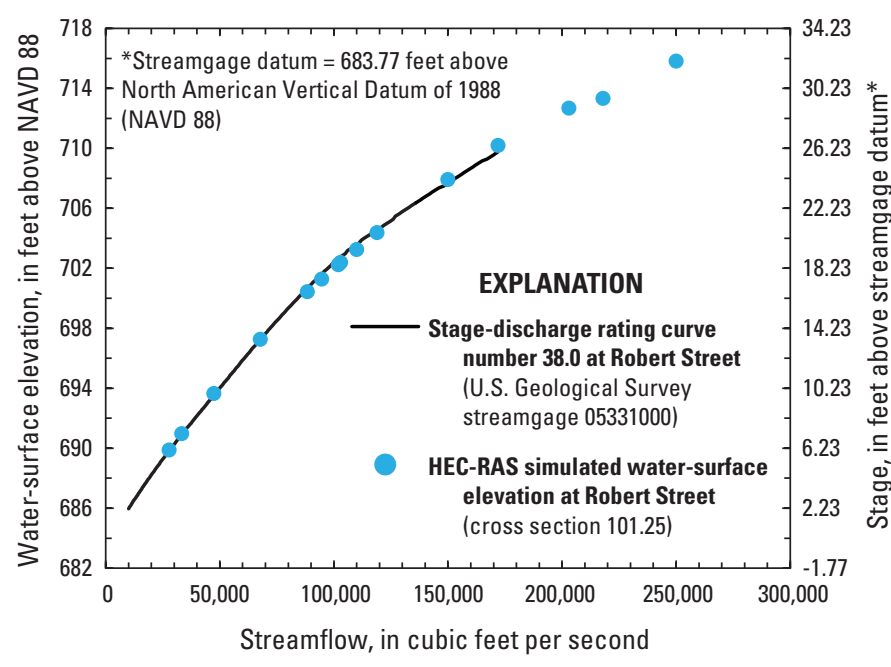

Figure 4. Model calibration to rating curve number 38.0 for the Mississippi River at Saint Paul.
Table 7. Comparison of calibrated hydraulic model water-surface elevations and rating curve number 38.0 for the Mississippi River at Saint Paul (U.S. Geological Survey streamgage 05331000).

$\left[\mathrm{ft}^{3} / \mathrm{s}\right.$, cubic feet per second; elevations are measured above North American Vertical Datum of 1988 (NAVD 88)]

\begin{tabular}{cccc}
\hline $\begin{array}{c}\text { Streamflow, } \\
\text { in ft }{ }^{3} / \mathbf{s}\end{array}$ & $\begin{array}{c}\text { Simulated } \\
\text { water-surface } \\
\text { elevation, } \\
\text { in feet }\end{array}$ & $\begin{array}{c}\text { Streamgage } \\
\text { water-surface } \\
\text { elevation }{ }^{1} \text {, } \\
\text { in feet }\end{array}$ & $\begin{array}{c}\text { Difference, } \\
\text { in feet }\end{array}$ \\
\hline 27,800 & 689.87 & 689.83 & 0.04 \\
\hline 33,400 & 690.96 & 690.93 & 0.03 \\
\hline 47,500 & 693.63 & 693.55 & 0.08 \\
\hline 67,800 & 697.26 & 697.27 & -0.01 \\
\hline 88,400 & 700.42 & 700.68 & -0.26 \\
\hline 94,700 & 701.28 & 701.63 & -0.35 \\
\hline 102,000 & 702.24 & 702.67 & -0.43 \\
103,000 & 702.37 & 702.77 & -0.40 \\
\hline 110,000 & 703.25 & 703.57 & -0.32 \\
\hline 119,000 & 704.36 & 704.57 & -0.21 \\
\hline 150,000 & 707.90 & 707.67 & 0.23 \\
\hline 172,000 & 710.19 & 709.77 & 0.42 \\
\hline
\end{tabular}

${ }^{1}$ From stage-discharge rating curve number 38.0 at Robert Street; datum elevation $=683.77$ feet above NAVD 88 .

to the existing FISs (fig. 5). The calibration and verification results demonstrate that the model is capable of simulating accurate water levels through the reach over a wide range of streamflows.

\section{Development of Water-Surface Profiles}

Water-surface profiles were developed for a total of 25 stages at 1-ft intervals from $9 \mathrm{ft}$ through $33 \mathrm{ft}$ as referenced to the Robert Street location of the Mississippi River at Saint Paul streamgage (05331000). These 25 profiles (table 8) were computed using the HEC-RAS model, and results were exported to ArcMap using the HEC-GeoRAS application. Streamflows corresponding to the various stages were obtained from the most recent stage-discharge relation (rating curve number 38.0) at the Robert Street location of the Mississippi River at Saint Paul streamgage (05331000). For streamflows that exceed the 1965 flood of record, the calibrated hydraulic model was used to extend the stage-discharge relation. The extension of the stage-discharge relation assumes that values of the hydraulic parameters (such as roughness coefficients) determined in the calibration process are also applicable for the extreme floods. Because streamflows have not been observed at these extreme levels, the stage-discharge relation and the resulting water-surface profile through the reach may differ from what is presented in this report. 


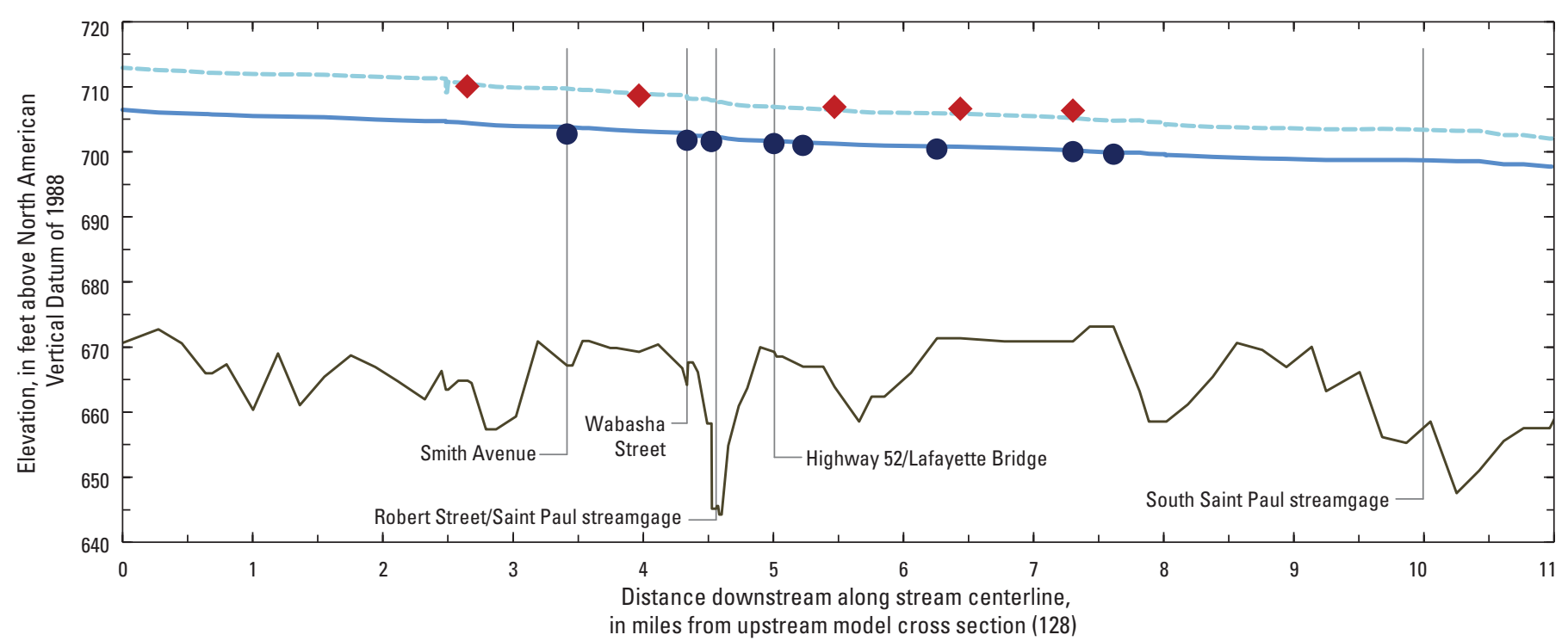

EXPLANATION

$--\quad$ 150,000 cubic feet per second; simulated water-surface profile
March 2011 flood peak; simulated water-surface profile
Channel thalweg
Flood insurance study (FIS); 1.0-percent exceedance flow
March 2011 flood peak; observed high-water mark

Figure 5. Comparison of simulated water-surface profiles, the 2011 observed high-water marks, and the flood profile for the existing Flood Insurance Study 1.0-percent exceedance flow.

\section{Levee Profiles}

Using the 25 simulated water-surface profiles, information was produced for the city of Saint Paul to quantify the water-surface elevations along each of the four levees within the inundation mapping reach for operations during flood events. The water-surface profiles are shown with the corresponding levee elevation for each cross-section location in the hydraulic model (fig. 6). Additionally, table 9 quantifies these elevations for selected cross sections of interest along each of the four levees. The Xcel Plant / River Bend Development and the Saint Paul Airport levees are both topped at a stage between 27 and 28 feet. The Saint Paul and the Pig's Eye WWTP levees are both topped at a stage of 33 feet.

\section{Development of Flood-Inundation Maps}

Flood-inundation maps were constructed for the Mississippi River within Saint Paul, Minnesota. The maps were developed using ArcMap software (Esri, Redlands, Calif.) by combining simulated water-surface elevations with a highresolution topography data.

Lidar topography data collected in 2011 were available from the Minnesota Department of Natural Resources as a 1-meter (3-ft) DEM, with a vertical accuracy of 5 centimeters, or 1.97 in. (Fugro Horizons, Inc., and Minnesota Department of Natural Resources, 2013). During the development of the flood-inundation maps, errors in the elevations of a raised section of Shepard Road and a section of railroad grade in the Lowertown area were discovered; they were classified as bridge elevations and not available in the bare-earth topography. The individual point cloud data points, in LAS format, were downloaded and used to patch the correct elevations into the lidar DEM. This corrected lidar DEM was used only for mapping, and is not represented in the hydraulic model.

Estimated flood-inundation boundaries for each simulated water-surface profile from the HEC-RAS model were developed with HEC-GeoRAS software (U.S. Army Corps of Engineers, 2009). HEC-GeoRAS is a set of procedures, tools, and utilities for processing geospatial data in ArcMap by using a graphical user interface (Whitehead and Ostheimer, 2009). The interface allows the preparation of geometric data for import into HEC-RAS and processes simulation results exported from HEC-RAS (U.S. Army Corps of Engineers, 2010). Cross-section lines and simulated water-surface elevations were extracted from the HEC-RAS model and imported into ArcMap. Each cross-section line had a series of attributes of the simulated water-surface elevations for each of the specific predefined streamgage stages. A water-level surface (profile) was generated for each predefined streamgage stage. 
Table 8. Stage, water-surface elevation, and streamflow simulated in the hydraulic model for development of floodinundation maps for the Mississippi River at Saint Paul (U.S. Geological Survey streamgage 05331000).

[Stage is referenced to the local gage datum, which is 683.77 feet above NAVD 88; NAVD 88, North American Vertical Datum of 1988; $\mathrm{ft}^{3} / \mathrm{s}$, cubic feet per second]

\begin{tabular}{|c|c|c|}
\hline Stage, in feet & $\begin{array}{l}\text { Water-surface } \\
\text { elevation, in feet } \\
\text { above NAVD 88, } \\
\text { rounded }\end{array}$ & $\begin{array}{c}\text { Streamflow, } \\
\text { in } \mathrm{ft}^{3} / \mathrm{s}\end{array}$ \\
\hline 9 & 692.8 & 43,300 \\
\hline 10 & 693.8 & 48,300 \\
\hline 11 & 694.8 & 53,700 \\
\hline 12 & 695.8 & 59,400 \\
\hline 13 & 696.8 & 65,000 \\
\hline 14 & 697.8 & 70,700 \\
\hline 15 & 698.8 & 76,800 \\
\hline 16 & 699.8 & 83,700 \\
\hline 17 & 700.8 & 91,000 \\
\hline 18 & 701.8 & 98,400 \\
\hline 19 & 702.8 & 106,200 \\
\hline 20 & 703.8 & 114,200 \\
\hline 21 & 704.8 & 122,400 \\
\hline 22 & 705.8 & 130,900 \\
\hline 23 & 706.8 & 139,700 \\
\hline 24 & 707.8 & 148,800 \\
\hline 25 & 708.8 & 158,200 \\
\hline 26 & 709.8 & 167,900 \\
\hline 27 & 710.8 & ${ }^{1} 177,900$ \\
\hline 28 & 711.8 & ${ }^{1} 186,600$ \\
\hline 29 & 712.8 & ${ }^{1} 207,200$ \\
\hline 30 & 713.8 & ${ }^{1} 223,200$ \\
\hline 31 & 714.8 & 1236,500 \\
\hline 32 & 715.8 & ${ }^{1} 249,500$ \\
\hline 33 & 716.8 & ${ }^{1} 261,600$ \\
\hline
\end{tabular}

${ }^{1}$ Streamflow exceeds the measured flood of record and is estimated according to the U.S. Army Corps of Engineers' extension of the rating curve.

An inundation surface and a water depth grid were developed for each profile by subtracting the ground-surface DEM from the water-level-surface elevations for each grid cell.

USGS personnel then modified the HEC-GeoRAS results to ensure a hydraulically reasonable transition of the boundary between modeled cross sections relative to the contour data for the land surface (Whitehead and Ostheimer, 2009). The flood-inundation boundaries have a rectilinear appearance that reflects the raster cells of the underlying lidar grid.
Disconnected flooded areas were removed from the maps when it was determined they were not hydraulically connected to the main channel inundation, such as with a culvert or stream. Areas behind a levee are shown as dry until that levee has been topped according to elevations in the HEC-RAS model cross sections.

Two areas in the inundation maps had additional edits to account for the temporary measures that supplement the primary levee systems at the Xcel Plant property and at the Saint Paul Airport. Behind the Xcel Plant / River Bend Development levee for a stage of 25 to $27 \mathrm{ft}$, the area of inundation is connected to the main channel at the downstream end, and as such, was mapped as a flat backwater elevation, rather than using the water-surface profile from the adjacent cross sections. The alignment of the planned temporary flood barriers and earthen walls on the northeast edge of the Xcel Plant property, which block spillover flooding at stages of 26 and $27 \mathrm{ft}$ until the levee is overtopped at $28 \mathrm{ft}$, were included in the map.

At the Saint Paul Airport, the inundation maps indicated that floodwaters can back up at the downstream (south) end of the property and inundate behind the airport levee before the levee is topped at $28 \mathrm{ft}$. For stages of 26 and $27 \mathrm{ft}$, several closure structures and other temporary measures were incorporated into the inundation mapping including a retaining wall, a closure structure, and sandbagging/construction of earthen closures, in accordance with the Metropolitan Airport Commission (Pat Mosites, Metropolitan Airport Commission, oral commun., 2013).

The HEC-RAS model was constructed using North American Datum of 1983 (NAD 83) Albers projection in survey feet, and so all initial mapping steps also were completed in this projection. The lidar data that were downloaded and mosaicked together were projected into NAD 83 Albers and resampled to a $3-\mathrm{ft}$ grid resolution. The near-final inundation maps were projected to World Geodetic System 1984 (WGS 84) Web Mercator (Auxiliary Sphere) in meters to properly align with the base map imagery on the NWS and USGS inundation mapping Web pages. At this step, inundation at bridge locations was edited based on Bing Map imagery available in ArcMap (Esri, Redlands, Calif.). A bridge is shown as inundated by (1) the lowest stage that intersects the lowest structural chord, or (2) the lowest stage that completely inundates an approach to the bridge, thus rendering it impassable by non-emergency vehicles. If neither of these conditions applies, then a bridge deck is removed from the inundation area for all mapped stages. Roadway overpasses over land also were clipped from the inundation area if the road approach on both sides of the bridge was not inundated; however, no elevation information about these overpass bridges was used in this analysis, and as such these bridges may be dangerous to cross during periods of high streamflow.

The resulting inundation maps have a vertical accuracy of $\pm 1.0 \mathrm{ft}$. The maps show estimated flood-inundated areas overlaid on high-resolution, geo-referenced, aerial photographs (U.S. Department of Agriculture, 2010) of the study 

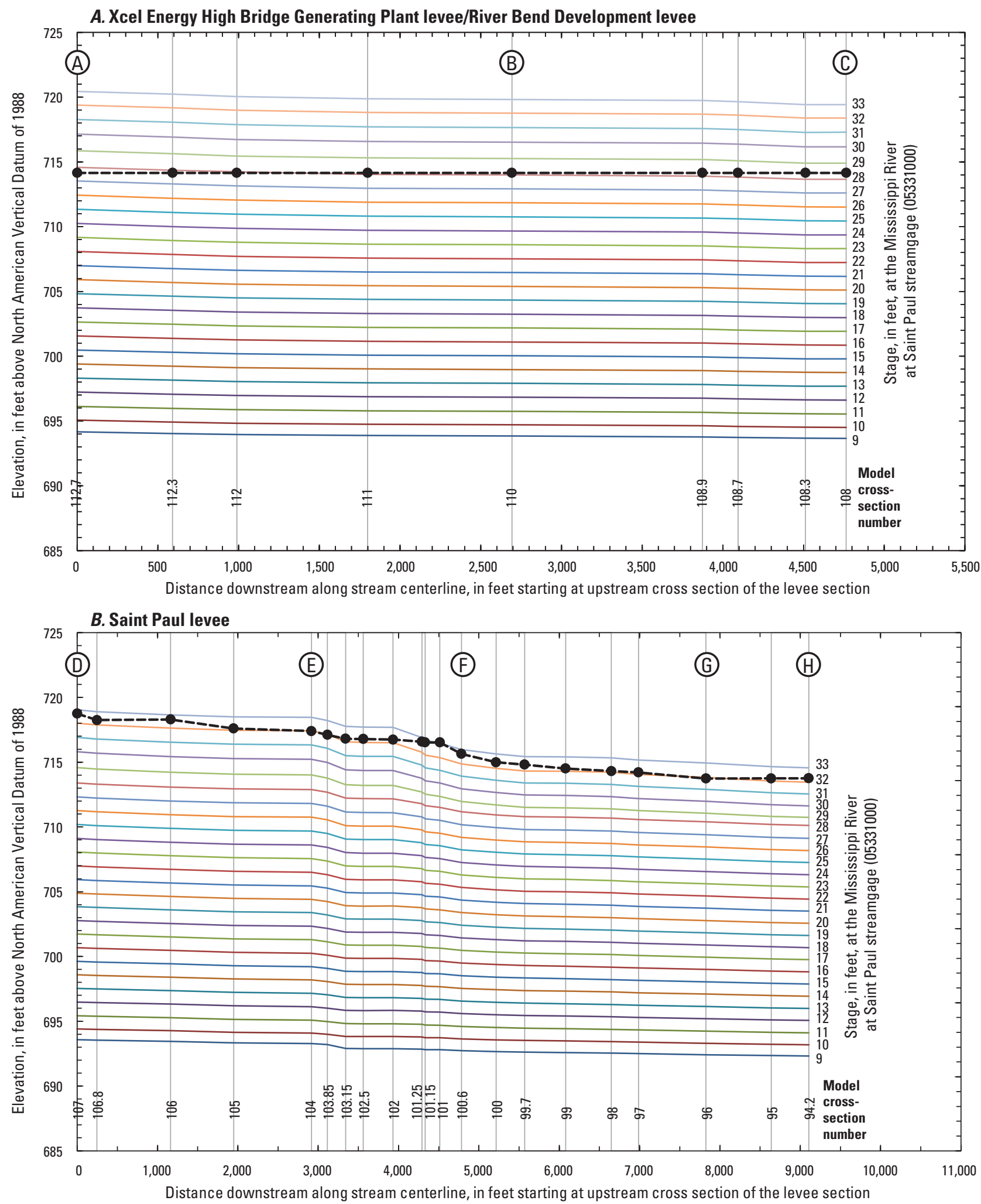

EXPLANATION

- - Levee elevation-elevation is evaluated only at cross-section location

(A) Cross section of interest with identifier (fig. 2)

Figure 6. Water-surface elevation profiles along the $A$, Xcel Energy High Bridge Generating Plant/River Bend Development, $B$, Saint Paul, $C$, Saint Paul Airport, and $D$, Pig's Eye Wastewater Treatment Plant levees. 


\section{Saint Paul Airport levee}

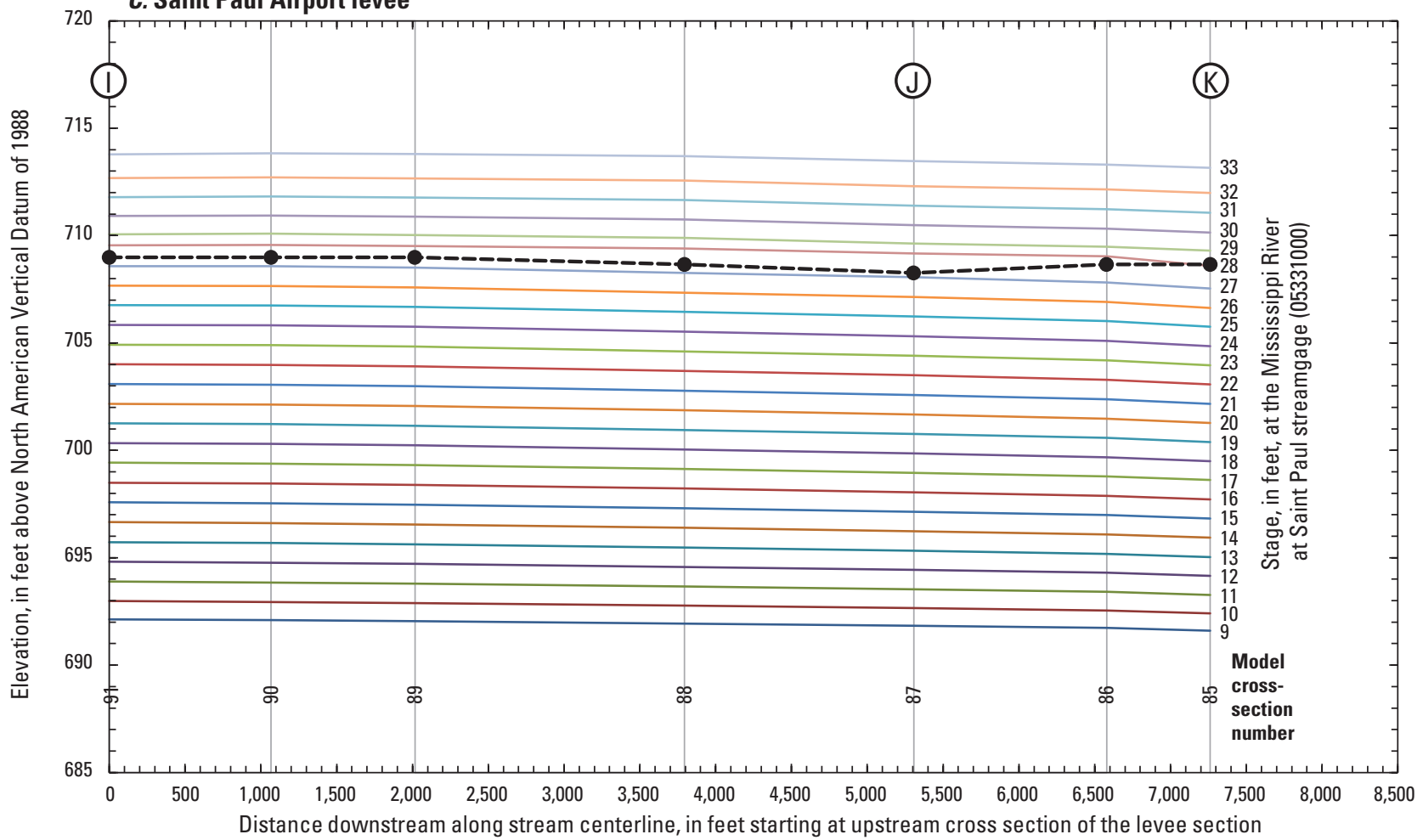

\section{Pig's Eye Wastewater Treatment Plant levee}

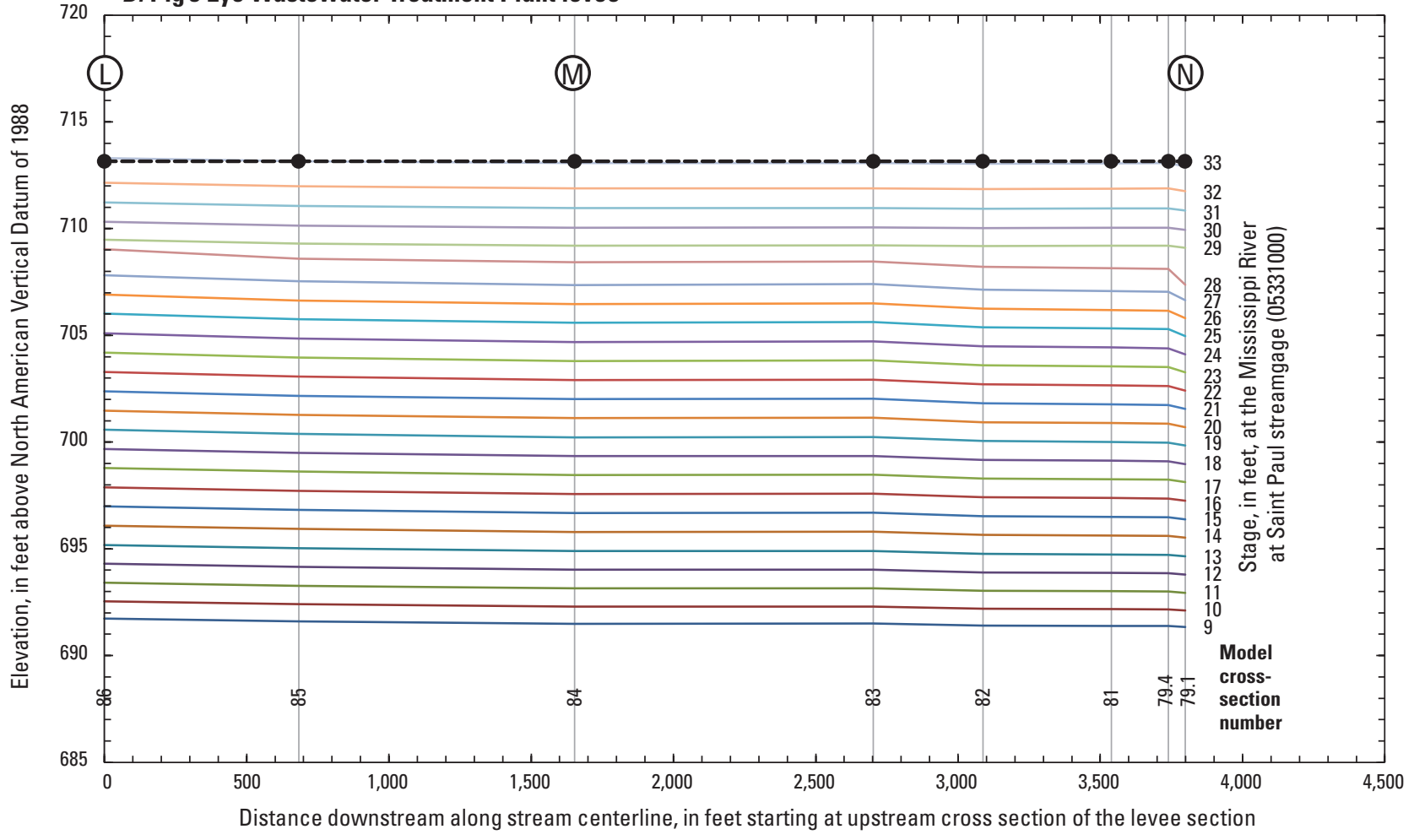

EXPLANATION

- Levee elevation-elevation is evaluated only at cross-section location

(A) Cross section of interest with identifier (fig. 2)

Figure 6. Water-surface elevation profiles along the $A$, Xcel Energy High Bridge Generating Plant/River Bend Development, $B$, Saint Paul, $C$, Saint Paul Airport, and D, Pig's Eye Wastewater Treatment Plant levees.-Continued 
Table 9. Simulated water-surface elevations at selected locations along levees.

[Elevations are measured above North American Vertical Datum of 1988 (NAVD 88); bold italicized values indicate water-surface elevations that exceed the levee elevation; stage is referenced to the local gage datum, which is 683.77 feet above NAVD 88; WWTP, wastewater treatment plant]

\begin{tabular}{|c|c|c|c|c|c|c|c|c|}
\hline \multirow{4}{*}{$\begin{array}{c}\text { Map label (fig. 2) } \\
\text { Model cross section } \\
\text { (fig. 2) } \\
\text { Levee elevation, } \\
\text { in feet }\end{array}$} & \multicolumn{3}{|c|}{$\begin{array}{c}\text { Xcel Energy High Bridge } \\
\text { Generating Plant/River Bend } \\
\text { Development }\end{array}$} & \multicolumn{5}{|c|}{ Saint Paul } \\
\hline & A & B & C & D & $\mathbf{E}$ & $\mathbf{F}$ & G & H \\
\hline & 112.7 & 110 & 108 & 107 & 104 & 100.6 & 96 & 94.2 \\
\hline & 714.15 & 714.15 & 714.15 & 719.53 & 718.35 & 716.81 & 715.14 & 715.16 \\
\hline $\begin{array}{c}\text { Streamgage stage, } \\
\text { in feet }\end{array}$ & & & & face elev & $n$, in feet & & & \\
\hline 33 & 720.43 & 719.81 & 719.43 & 719.05 & 718.47 & 715.98 & 714.94 & 714.56 \\
\hline 32 & 719.38 & 718.76 & 718.39 & 718.01 & 717.41 & 714.86 & 713.83 & 713.45 \\
\hline 31 & 718.28 & 717.66 & 717.28 & 716.92 & 716.33 & 713.91 & 712.91 & 712.54 \\
\hline 27 & 713.53 & 712.92 & 712.59 & 712.33 & 711.82 & 710.17 & 709.40 & 709.12 \\
\hline 26 & 712.44 & 711.84 & 711.52 & 711.26 & 710.75 & 709.19 & 708.45 & 708.18 \\
\hline 25 & 711.35 & 710.76 & 710.44 & 710.19 & 709.69 & 708.24 & 707.52 & 707.26 \\
\hline 24 & 710.24 & 709.67 & 709.36 & 709.11 & 708.61 & 707.26 & 706.56 & 706.31 \\
\hline 23 & 709.17 & 708.60 & 708.30 & 708.06 & 707.56 & 706.29 & 705.62 & 705.38 \\
\hline 22 & 708.08 & 707.53 & 707.23 & 706.99 & 706.51 & 705.32 & 704.67 & 704.44 \\
\hline 21 & 706.98 & 706.46 & 706.17 & 705.93 & 705.45 & 704.35 & 703.72 & 703.50 \\
\hline 20 & 705.91 & 705.39 & 705.11 & 704.89 & 704.42 & 703.38 & 702.78 & 702.56 \\
\hline 14 & 699.40 & 698.97 & 698.74 & 698.59 & 698.20 & 697.54 & 697.10 & 696.94 \\
\hline 13 & 698.32 & 697.91 & 697.68 & 697.54 & 697.16 & 696.56 & 696.14 & 695.99 \\
\hline 12 & 697.23 & 696.84 & 696.62 & 696.49 & 696.13 & 695.59 & 695.20 & 695.06 \\
\hline 11 & 696.12 & 695.75 & 695.54 & 695.42 & 695.08 & 694.60 & 694.24 & 694.11 \\
\hline 10 & 695.06 & 694.71 & 694.51 & 694.40 & 694.08 & 693.63 & 693.30 & 693.19 \\
\hline 9 & 694.17 & 693.84 & 693.66 & 693.57 & 693.28 & 692.72 & 692.42 & 692.32 \\
\hline
\end{tabular}


Table 9. Simulated water-surface elevations at selected locations along levees. - Continued

[Elevations are measured above North American Vertical Datum of 1988 (NAVD 88); bold italicized values indicate water-surface elevations that exceed the levee elevation; stage is referenced to the local gage datum, which is 683.77 feet above NAVD 88; WWTP, wastewater treatment plant]

\begin{tabular}{|c|c|c|c|c|c|c|}
\hline \multirow{2}{*}{$\begin{array}{c}\text { Levee } \\
\text { Map label (fig. 2) }\end{array}$} & \multicolumn{3}{|c|}{ Saint Paul Airport } & \multicolumn{3}{|c|}{ Pig's Eye WWTP } \\
\hline & I & $\mathbf{J}$ & K & $\mathbf{L}$ & M & $\mathbf{N}$ \\
\hline $\begin{array}{l}\text { Model cross section } \\
\text { (fig. 2) }\end{array}$ & 91 & 87 & 85 & 86 & 84 & 79.1 \\
\hline $\begin{array}{c}\text { Levee elevation, } \\
\text { in feet }\end{array}$ & 708.98 & 708.26 & 708.65 & 713.15 & 713.15 & 713.15 \\
\hline $\begin{array}{c}\text { Streamgage stage, } \\
\text { in feet }\end{array}$ & \multicolumn{6}{|c|}{ Water-surface elevation, in feet } \\
\hline 33 & 713.79 & 713.47 & 713.16 & 713.31 & 713.07 & 712.92 \\
\hline 32 & 712.67 & 712.31 & 711.98 & 712.15 & 711.88 & 711.76 \\
\hline 31 & 711.79 & 711.39 & 711.06 & 711.23 & 710.96 & 710.84 \\
\hline 30 & 710.91 & 710.48 & 710.14 & 710.33 & 710.04 & 709.94 \\
\hline 29 & 710.07 & 709.64 & 709.30 & 709.48 & 709.20 & 709.11 \\
\hline 28 & 709.55 & 709.17 & 708.59 & 709.03 & 708.42 & 707.36 \\
\hline 27 & 708.58 & 708.06 & 707.53 & 707.81 & 707.36 & 706.65 \\
\hline 26 & 707.66 & 707.14 & 706.64 & 706.90 & 706.47 & 705.80 \\
\hline 25 & 706.76 & 706.24 & 705.76 & 706.01 & 705.59 & 704.97 \\
\hline 24 & 705.84 & 705.32 & 704.86 & 705.10 & 704.69 & 704.11 \\
\hline 23 & 704.92 & 704.41 & 703.96 & 704.20 & 703.80 & 703.26 \\
\hline 22 & 704.00 & 703.49 & 703.07 & 703.29 & 702.91 & 702.41 \\
\hline 21 & 703.09 & 702.58 & 702.17 & 702.38 & 702.01 & 701.55 \\
\hline 20 & 702.17 & 701.67 & 701.28 & 701.48 & 701.12 & 700.70 \\
\hline 19 & 701.25 & 700.76 & 700.38 & 700.58 & 700.23 & 699.84 \\
\hline 18 & 700.33 & 699.85 & 699.49 & 699.68 & 699.34 & 698.97 \\
\hline 17 & 699.42 & 698.96 & 698.61 & 698.79 & 698.46 & 698.12 \\
\hline 16 & 698.50 & 698.04 & 697.72 & 697.88 & 697.57 & 697.25 \\
\hline 15 & 697.57 & 697.14 & 696.83 & 696.99 & 696.68 & 696.38 \\
\hline 14 & 696.65 & 696.24 & 695.94 & 696.09 & 695.79 & 695.52 \\
\hline 13 & 695.72 & 695.32 & 695.04 & 695.18 & 694.90 & 694.64 \\
\hline 12 & 694.81 & 694.43 & 694.16 & 694.30 & 694.03 & 693.79 \\
\hline 11 & 693.88 & 693.53 & 693.27 & 693.41 & 693.14 & 692.94 \\
\hline 10 & 692.98 & 692.65 & 692.41 & 692.54 & 692.29 & 692.11 \\
\hline 9 & 692.13 & 691.83 & 691.61 & 691.72 & 691.49 & 691.34 \\
\hline
\end{tabular}


area for each of the 25 water-surface profiles that were generated by the hydraulic model for 1-ft stage increments from 9 to $33 \mathrm{ft}$ (map sheets 1 to 25 available at http://pubs.usgs.gov/ sir/2014/5079/downloads/mapsheets01-25.pdf).

Flooding effects are evident in the inundation maps (map sheets 1 to 25). Vehicle transportation disruptions begin at a stage of $13 \mathrm{ft}$, when Water Street becomes inundated at the upstream end of the inundation mapping reach (sheet 5). At major flood stage $(17 \mathrm{ft})$, Harriet Island begins to become submerged (sheet 9), and at $18 \mathrm{ft}$ Shepard-Warner Road in downtown Saint Paul, near Robert Street, first becomes inundated (sheet 10). At $22 \mathrm{ft}$, Warner Road east of Lowertown is affected, and Raspberry Island is fully inundated (sheet 14). Flooding in Lowertown Saint Paul becomes extensive by $27 \mathrm{ft}$ (sheet 19). At a stage of $28 \mathrm{ft}$, the Xcel Plant / River Bend Development and Saint Paul Airport levees have been topped (sheet 20). The three railroads and railroad bridges become inundated at 28 and $29 \mathrm{ft}$ (sheets 20 and 21, respectively). At a stage of $33 \mathrm{ft}$, the Saint Paul and Pig's Eye WWTP levees have been topped, nearly inundating the area to the valley wall (sheet 25). At a stage of $33 \mathrm{ft}$, the only bridge approaches that remain elevated well above the water surface are for the bridge at Smith Avenue. Note, bridges may be dangerous to cross or closed at lower water levels than when shown as inundated in these maps because of safety concerns or other factors, such as pier scour.

\section{Flood-Inundation Map Library on the Internet}

The flood-inundation maps and study documentation for the Mississippi River at Saint Paul, Minnesota, are available online at the USGS Publications Warehouse (http://pubs. usgs.gov/sir/2014/5079). Current conditions for the USGS streamgage at the Mississippi River at Saint Paul (05331000) may be found at the following link: http://waterdata.usgs. gov/mn/nwis/uv/?site_no $=05331000$. The NWS AHPS forecasted stages for the Mississippi River at Saint Paul may be found at the following link: http://water.weather.gov/ahps2/ hydrograph.php? wfo $=m p x \&$ gage $=$ stpm 5 .

Also, a Flood Inundation Mapping Science Web site has been established at http://water.usgs.gov/osw/flood_ inundation/to provide a portal for USGS flood-inundation study information to the public. That Web portal has a link (http://wim.usgs.gov/FIMI/FloodInundationMapper.html) to all of the interactive online map libraries. At the map library site, each stream reach displayed contains additional links to graphs of the current stage and streamflow at the USGS streamgage to which the inundation maps are referenced. Flood-inundation maps also are available online through the NWS AHPS Inundation Mapping site (http://water.weather. gov/ahps/inundation.php). At both the USGS and the NWS AHPS mapping sites, the inundation maps can be downloaded in several commonly used electronic file formats.

The flood-inundation maps indicate extent, as well as depth, of the estimated flood inundation. The estimated flood-inundation maps are displayed in sufficient detail to note the extent of flooding with respect to individual structures for efficient preparations for flooding and decisions for emergency response, although the uncertainties and limitations described in this report must be considered. Roadways and bridges were closely reviewed and are shown as shaded (inundated and likely impassable) or not shaded (dry and passable) to facilitate emergency planning and use. However, buildings that are shaded do not reflect inundation but denote that bare earth surfaces in the vicinity of the buildings are inundated.

No evaluation was made to account for the possibility of levee failure before levee overtopping. Figure 1 indicates the levee risk area with hatched areas for the levees in the inundation mapping reach. The area of levee risk was identified on the landward (dry) side of each levee as the area that would be inundated if the levee were overtopped.

\section{Disclaimer for Flood-Inundation Maps}

Inundated areas shown should not be used for navigation, regulatory, permitting, or other legal purposes. The USGS provides these maps "as-is" for a quick reference, emergency planning tool but assumes no legal liability or responsibility resulting from the use of this information.

\section{Uncertainties and Limitations Regarding Use of Flood-Inundation Maps}

Although the flood-inundation maps represent the boundaries of inundated areas with a distinct line, some uncertainty is associated with these maps. The flood boundaries shown were estimated based on water stages (water-surface elevations) and streamflows (discharges) at the selected USGS streamgage (05331000), according to the stage-discharge rating curve number 38.0 at Robert Street, with a datum elevation of 683.77 feet above NAVD 88. Water-surface elevations along the Mississippi River were estimated by steady-state hydraulic modeling, assuming unobstructed flow, and using streamflows and hydrologic conditions anticipated at the USGS streamgage. The hydraulic model reflects the landcover characteristics and any bridge, dam, levee, or other hydraulic structures existing as of February 2013. It was assumed that any temporary parts of the four levees in the inundation mapping reach are constructed as designed before the flood. No other temporary measures within the study area, such as sandbagging, construction of earthen closures or private floodwalls, or pumping of floodwaters, are accounted for in the hydraulic modeling or inundation mapping. Unique meteorological factors (timing and distribution of precipitation) may cause actual streamflows along the modeled reach to vary from those assumed during a flood, which may lead to deviations in the water-surface elevations and subsequent flood boundaries. Additional uncertainty is inherent in the flood forecasts and inundation maps for streamflows above the flood of record in April 1965 (171,000 ft $3 / \mathrm{s}$; stage of $26.01 \mathrm{ft})$. 
These inundation maps only account for floodwaters that come from the Mississippi River; they do not account for any subsurface flow or interior drainage issues caused by local rainfall. Additional areas may be flooded because of unanticipated conditions such as changes in the streambed elevation or roughness, backwater into major tributaries along a main-stem river, or backwater from localized debris or ice jams. The accuracy of the floodwater extent portrayed on these maps will vary with the accuracy of the digital elevation model used to simulate the land surface. Additional uncertainties and limitations pertinent to this study are described elsewhere in this report.

If these flood-inundation maps are used in conjunction with National Weather Service (NWS) river forecasts, users need to be aware of additional uncertainties that may be inherent in NWS forecast procedures. The NWS uses forecast models to estimate the quantity and timing of water flowing through selected stream reaches in the United States. These forecast models (1) estimate the amount of runoff generated by recent and forecasted precipitation and snowmelt, (2) simulate the movement of floodwater as it proceeds downstream, and (3) predict the streamflow and stage for the stream at a given location (AHPS forecast point) throughout the forecast period (every 6 hours and 3 to 5 days out in many locations). For more information on AHPS forecasts, please access the following link: http://water.weather.gov/ahps/pcpn_and_river_ forecasting.pdf (National Weather Service, 2012).

\section{Summary}

Flooding of the Mississippi River in Saint Paul, Minnesota, has historically affected the left bank and the right bank. The greatest recorded flood peaked on April 16, 1965. Although much of the areas that previously flooded now have permanent levees in place, land behind the levees has been developed and the threat of levee failure or a catastrophic flood cannot be discounted.

A series of flood-inundation maps for a 6.3-mile reach of the Mississippi River in Saint Paul, Minnesota was developed through a multi-agency effort by the U.S. Geological Survey (USGS) in cooperation with the U.S. Army Corp of Engineers (USACE) and in collaboration with the National Weather Service (NWS). These maps, in conjunction with the real-time stage data from the USGS streamgage at Mississippi River at Saint Paul (05331000) and NWS flood-stage forecasts, provide enhanced flood warning and visualization of the potential effects of a forecasted flood for the city of Saint Paul and its residents. These maps will help to guide the general public in taking individual safety precautions and will provide city officials with a tool to efficiently manage emergency flood operations and flood mitigation efforts.

The maps were developed using the USACE HECRAS and HEC-GeoRAS programs to compute water-surface profiles and to delineate estimated flood-inundation areas for selected stream stages. A one-dimensional step-backwater hydraulic model was developed for the Mississippi River at Saint Paul from existing models, updated topography data, and additional structure information. The hydraulic model was calibrated using the most recent stage-discharge relation at the Robert Street location (rating curve number 38.0) of the USGS streamgage at the Mississippi River at Saint Paul (05331000), as well as an approximate water-surface elevation-discharge relation at the USACE streamgage at the Mississippi River at South Saint Paul (SSPM5). The model also was verified against observed high-water marks from the recent 2011 flood event and the water-surface profile from existing flood insurance studies. The hydraulic model was then used to determine 25 water-surface profiles for flood stages at 1 -foot intervals ranging from approximately bankfull stage to greater than the highest recorded stage at streamgage 05331000 . Water-surface profiles simulated in the hydraulic model were then combined with a geographic information system digital elevation model, derived from high-resolution topography data, to delineate estimated flood inundation and to determine the water depths within the inundated areas for each stage at streamgage 05331000 .

The 25 maps show estimated (shaded) flood-inundation areas overlaid on high-resolution, geo-referenced, aerial photographs of the study area for stream 1-foot stage increments from 9 through $33 \mathrm{ft}$ for the Mississippi River at Saint Paul (USGS streamgage 05331000). The maps are available through the USGS Flood Inundation Mapping Science Web site at http://water.usgs.gov/osw/flood_inundation/and the NWS Advanced Hydrologic Prediction Service Inundation Mapping site at http://water.weather.gov/ahps/inundation. $p h p$. Although the flood-inundation maps represent distinct boundaries of inundated areas, some uncertainties exist in each aspect of the hydraulic model, computational grid and inundation maps, and flood forecast hydrographs.

\section{References Cited}

Barr Engineering, 2012, Washington Street Flood Protection, Technical Memorandum to Xcel Energy August 10, 2012, $5 \mathrm{p}$.

Chow, V.T., 1959, Open-channel hydraulics: McGraw-Hill, New York, N.Y., 680 p.

Federal Emergency Management Agency, 2010a, Flood Insurance Study, Ramsey County, Minnesota (all jurisdictions): Federal Emergency Management Agency, 67 p.

Federal Emergency Management Agency, 2010b, Flood Insurance Study, Washington County, Minnesota, and incorporated areas: Federal Emergency Management Agency, $114 \mathrm{p}$. 
Federal Emergency Management Agency, 2011, Flood Insurance Study, Dakota County, Minnesota, and incorporated areas: Federal Emergency Management Agency, 310 p.

Fugro Horizons, Inc., and Minnesota Department of Natural Resources, 2013, LiDAR elevation, Twin Cities Metro Region, Minnesota, 2011: accessed March 22, 2013, at http://www.mngeo.state.mn.us/chouse/metadata/lidar_ metro2011.html.

Gesch, D., Oimoin, M., Greenlee, S., Nelson, C., Steuck, M., and Tyler, D., 2002, The National Elevation Dataset: Photogrammetric Engineering and Remote Sensing, v. 68, no. 1, p. $5-11$.

Kessler, E.W., Lorenz, D.L., and Sanocki, C.A., 2013, Methods and results of peak-flow frequency analyses for streamgages in and bordering Minnesota through water year 2011: U.S. Geological Survey Scientific Investigations Report 2013-5110, 43 p., accessed September 4, 2013, at http://pubs.usgs.gov/sir/2013/5110/.

Midwest Regional Climate Center, 2013, Historical climate data, precipitation summary, St. Paul, Minnesota: accessed May 23, 2013, at http://mcc.sws.uiuc.edu/climate_midwest/ historical/precip/mn/217377_psum.html.

Minnesota Department of Natural Resources, 1972, Mississippi River floodplain information and management, mile 815.2 to mile 847.7: St. Paul, Minn., Minnesota Division of Waters, Soils, and Minerals, 48 p.

Minnesota Geospatial Information Office, 2012, Minnesota LiDAR Research and Education Subcommittee-Glossary of LiDAR-related terms: accessed on December 13, 2012, at http://www.mngeo.state.mn.us/committee/elevation/ research_education/MnLiDARGlossary.pdf.

National Weather Service, 2012, A brief overview of the NWS precipitation and river forecasting and the river forecast on the AHPS hydrograph: accessed on December 13, 2012, at http://water.weather.gov/ahps/pcpn_and_river_forecasting. $p d f$.

National Weather Service, 2013, Evolution of the National Weather Service: Public Affairs Office, accessed on July 1, 2013, at http://www.nws.noaa.gov/pa/history/timeline.php.

Paulhus, J.L.H., and Nelson, E.R., 1967, The March-May 1965 Floods in the Upper Mississippi, Missouri and Red River of the North Basins: U.S. Department of Commerce and Environmental Science Services Administration, Weather Bureau WB-4, $100 \mathrm{p}$.

Rantz, S.E., and others, 1982, Measurement and computation of streamflow: U.S. Geological Survey Water-Supply Paper 2175, 631 p., accessed September 6, 2013, at http://pubs. usgs.gov/wsp/wsp2175/.
U.S. Army Corps of Engineers, 1991, HEC-2, Water Surface Profiles, User's manual: U.S. Army Corps of Engineers, Hydrologic Engineering Center, 334 p.

U.S. Army Corps of Engineers, 1997, Flood Control Project, Mississippi River, St. Paul, Minnesota-Operation and maintenance manual: U.S. Army Corps of Engineers, St. Paul District, $150 \mathrm{p}$.

U.S. Army Corps of Engineers, 2003, Water Control Manual, Mississippi River Nine-Foot Channel Navigation Project, Appendix 2 of the Master Water Control Manual—Lock and Dam No. 2, Hastings, Minnesota: U.S. Army Corps of Engineers, [variously paged].

U.S. Army Corps of Engineers, 2009, HEC-GeoRAS, GIS tools for support of HEC-RAS using ArcGIS, User's manual, version 4.2: U.S. Army Corps of Engineers, Hydrologic Engineering Center, [variously paged].

U.S. Army Corps of Engineers, 2010, HEC-RAS River Analysis System, Hydraulic Reference Manual, version 4.1: U.S. Army Corps of Engineers, Hydrologic Engineering Center [variously paged].

U.S. Census Bureau, 2012, St. Paul Minnesota quickfacts: accessed on December 4, 2012, at http://quickfacts.census. gov/qfd/states/27/2758000.html.

U.S. Department of Agriculture, 1940, Report on river gauge station for the Mississippi River at St. Paul: Weather Bureau Form 4004B-MIS.

U.S. Department of Agriculture, 2010, National Agricultural Imagery Program (NAIP) digital orthorectified images (DOQ), Minnesota, 2010: accessed April 11, 2013, at http:// nationalmap.gov/viewer.html.

U.S. Department of Commerce, 1954, Floods of 1952-Upper Mississippi-Missouri-Red River of the North: Washington, D.C., Hydrologic Services Division, Weather Bureau Technical Paper 23, 93 p.

U.S. Department of Commerce and National Oceanic and Atmospheric Administration, 1994, Natural disaster survey report-The Great Flood of 1993: U.S. Department of Commerce, [variously paged].

U.S. Geological Survey, 1912, Surface water supply of the United States, 1910, Part V, Hudson Bay and Upper Mississippi River Basin: U.S. Geological Survey Water Supply Paper 285, 318 p. (Also available at http://pubs.er.usgs.gov/ publication/wsp285.)

U.S. Geological Survey, 2013a, National Water Information System - Peak streamflow for Minnesota, USGS 05331000 Mississippi River at St. Paul, MN: U.S. Geological Survey database, accessed May 31, 2013, at http://nwis.waterdata. usgs.gov/mn/nwis/peak/?site_no $=05331000 \&$ agency $c d=U S G S$. 
U.S. Geological Survey, 2013b, National Water Information System- Streamflow Measurements for Minnesota, USGS 05331000 Mississippi River at St. Paul, MN: U.S. Geological Survey database, accessed May 31, 2013, at http://waterdata.usgs.gov/mn/nwis/measurements/?site $n o=05331000 \&$ agency_cd $=U S G S$.

U.S. Geological Survey, 2013c, National Water Information System-USGS surface-water monthly statistics for the Nation, USGS 05331000 Mississippi River at St. Paul, MN: U.S. Geological Survey database, accessed May 24, 2013, at http://waterdata.usgs.gov/ nwis/monthly/?referred_module $=$ sw\&site_no $=053310$ 00\&por_05331000_3=-900461,00060,3,1892-03,2012$09 \&$ format $=$ html_table\&date_format $=Y Y Y Y-M M$ DD\&rdb_compression=file\&submitted_form = parameter selection_list.
Wells, J.V.B., 1955, Floods of 1952 in the basins of the Upper Mississippi River and Red River of the North: U.S. Geological Survey Water-Supply Paper 1260-C, 240 p., accessed July 1, 2013, at http://pubs.usgs.gov/wsp/1260c/report.pdf.

Whitehead, M.T., and Ostheimer, C.J., 2009, Development of a flood-warning system and flood-inundation mapping for the Blanchard River in Findlay, Ohio: U.S. Geological Survey Scientific Investigations Report 2008-5234, 9 p., accessed September 4, 2013, at http://pubs.usgs.gov/ $\operatorname{sir} / 2008 / 5234 /$. 
Appendix 


\section{Appendix. Flood Inundation Maps}

Map sheets and additional materials are available online at $h t t p: / / p u b s . u s g s . g o v /$ sir/2014/5079/downloads/.

Flood-inundation maps of the Mississippi River at Saint Paul, Minnesota, at the U.S. Geological Survey streamgage 05331000 for a corresponding stage of-

1. 9.0 feet and an elevation of 692.8 feet above North American Vertical Datum of 1988.

2. 10.0 feet and an elevation of 693.8 feet above North American Vertical Datum of 1988.

3. 11.0 feet and an elevation of 694.8 feet above North American Vertical Datum of 1988.

4. 12.0 feet and an elevation of 695.8 feet above North American Vertical Datum of 1988.

5. 13.0 feet and an elevation of 696.8 feet above North American Vertical Datum of 1988 .

6. 14.0 feet and an elevation of 697.8 feet above North American Vertical Datum of 1988 .

7. 15.0 feet and an elevation of 698.8 feet above North American Vertical Datum of 1988 .

8. 16.0 feet and an elevation of 699.8 feet above North American Vertical Datum of 1988 .

9. 17.0 feet and an elevation of 700.8 feet above North American Vertical Datum of 1988 .

10. 18.0 feet and an elevation of 701.8 feet above North American Vertical Datum of 1988 .

11. 19.0 feet and an elevation of 702.8 feet above North American Vertical Datum of 1988 .

12. 20.0 feet and an elevation of 703.8 feet above North American Vertical Datum of 1988 .

13. 21.0 feet and an elevation of 704.8 feet above North American Vertical Datum of 1988 .

14. 22.0 feet and an elevation of 705.8 feet above North American Vertical Datum of 1988 .

15. 23.0 feet and an elevation of 706.8 feet above North American Vertical Datum of 1988.

16. 24.0 feet and an elevation of 707.8 feet above North American Vertical Datum of 1988.

17. 25.0 feet and an elevation of 708.8 feet above North American Vertical Datum of 1988 .

18. 26.0 feet and an elevation of 709.8 feet above North American Vertical Datum of 1988 .

19. 27.0 feet and an elevation of 710.8 feet above North American Vertical Datum of 1988 .

20. 28.0 feet and an elevation of 711.8 feet above North American Vertical Datum of 1988.

21. 29.0 feet and an elevation of 712.8 feet above North American Vertical Datum of 1988.

22. 30.0 feet and an elevation of 713.8 feet above North American Vertical Datum of 1988 .

23. 31.0 feet and an elevation of 714.8 feet above North American Vertical Datum of 1988 .

24. 32.0 feet and an elevation of 715.8 feet above North American Vertical Datum of 1988.

25. 33.0 feet and an elevation of 716.8 feet above North American Vertical Datum of 1988. 
Publishing support provided by: Rolla Publishing Service Center

For more information concerning this publication, contact: Director, USGS Minnesota Water Science Center 2280 Woodale Drive

Mounds View, Minnesota 55112

(763) 783-3100 


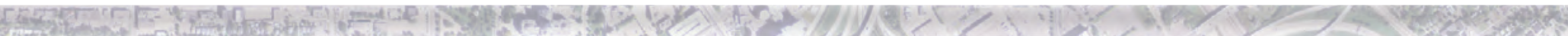
and
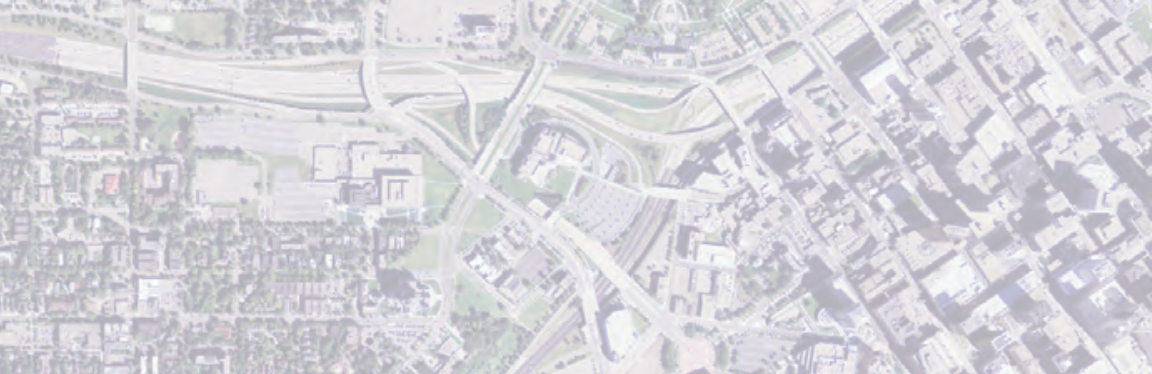

$\mathrm{x}^{2}=$
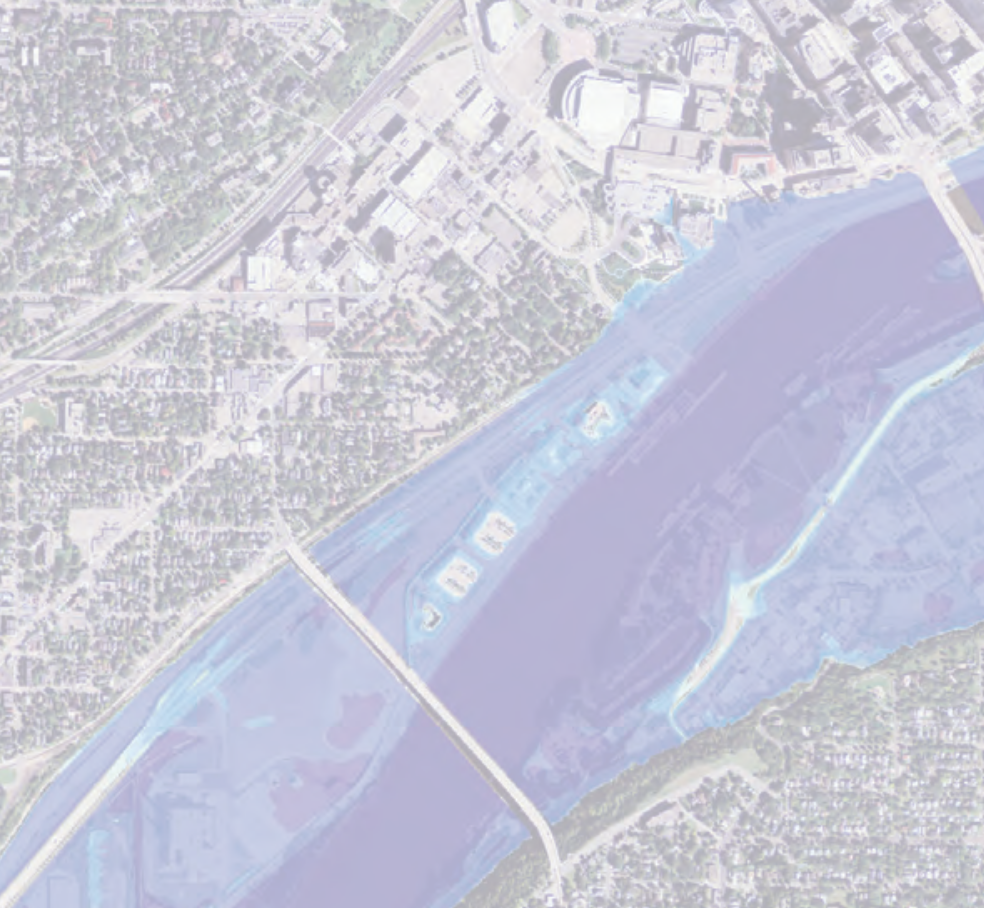